\title{
Late Quaternary glaciations in Far NE Russia; combining moraines, topography and chronology to assess regional and global glaciation synchrony
}

\author{
Iestyn D. Barr \& Chris D. Clark
}

School of Geography, Queen Mary University of London, Mile End Road, London E1 4NS, UK

Department of Geography, University of Sheffield, Winter Street, Sheffield S10 2TN, UK

This is an author produced version of a paper published in Quaternary Science Reviews

\section{Published paper}

Barr, ID., Clark, CD. (2012) Late Quaternary glaciations in Far NE Russia; combining moraines, topography and chronology to assess regional and global glaciation synchrony. Quaternary Science Reviews, 53, 72-87. doi: 10.1016/j.quascirev.2012.08.004

http://www.sciencedirect.com/science/article/pii/S0277379112003046 


\section{Abstract}

During various periods of Late Quaternary glaciation, small ice-sheets, -caps, -fields and valley glaciers, occupied the mountains and uplands of Far NE Russia (including the Verkhoyansk, Suntar-Khayata, and Chersky Mountains; the Kolyma-Anyuy and Koryak Highlands; and much of the Kamchatka and Chukchi peninsulas). Here, the margins of former glaciers across this region are constrained through the comprehensive mapping of moraines from remote sensing data (Landsat 7 ETM+ satellite images; ASTER Global Digital Elevation Model (GDEM2); and Viewfinder Panorama DEM data). A total of 8414 moraines are mapped, and this record is integrated with a series of published age-estimates (n $=25$, considered to chronologically-constrain former ice-margin positions. Geomorphological and chronological data are compiled in a Geographic Information System (GIS) to produce 'best estimate' reconstructions of ice extent during the global Last Glacial Maximum (gLGM) and, to a lesser degree, during earlier phases of glaciation. The data reveal that much of Far NE Russia $\left(\sim 1,092,427 \mathrm{~km}^{2}\right)$ preserves a glaciated landscape (i.e. is bounded by moraines), but there is no evidence of former ice masses having extended more than $270 \mathrm{~km}$ beyond mountain centres (suggesting that, during the Late Quaternary, the region has not been occupied by extensive ice sheets). During the gLGM, specifically, glaciers occupied $\sim 253,000 \mathrm{~km}^{2}$, and rarely extended more than $50 \mathrm{~km}$ in length. During earlier (pre-gLGM) periods, glaciers were more extensive, though the timing of former glaciation, and the maximum Quaternary extent, appears to have been asynchronous across the region, and out-of-phase with ice-extent maxima elsewhere in the Northern Hemisphere. This glacial history is partly explained through consideration of climatic-forcing (particularly moisture-availability, solar insolation and albedo), though topographic-controls upon the former extent and dynamics of glaciers are also considered, as are topographic-controls upon moraine deposition and preservation. Ultimately, our ability to understand the glacial and climatic history of this region is restricted when the geomorphological-record alone is considered, particularly as directly-dated glacial deposits are few, and topographic and climatic controls upon the moraine record are difficult to distinguish. 


\section{Introduction}

Until recently, considerable uncertainty persisted about the extent of former glaciers in Far NE Russia. Some argued that, during much of the Late Quaternary (particularly the global Last Glacial Maximum: gLGM), the region was covered by a series of large and coalescing ice sheets (see Grosswald, 1998; Grosswald and Hughes, 2002), but recent investigations demonstrate this not to have been the case (see Brigham-Grette et al., 2003; Stauch et al., 2007; Stauch and Gualtieri., 2008; Stauch and Lehmkuhl, 2010, 2011; Barr and Clark, 2009, 2011; Glushkova, 2011; Nürnberg et al., 2011; Zech et al., 2011). Much of the evidence now points to a mountain-centred style of glaciation during most of the last glacial cycle (past $\sim 140 \mathrm{ka}$ ), with small ice-sheets, -caps, -fields and valley glaciers, emanating from many of the region's uplands. Thus, the dimensions of palaeoglaciers are becoming better resolved, but chronological-constraints upon former periods of glaciation remain poor. There is some evidence for regionally-asynchronous glaciation across Far NE Russia, particularly during the gLGM (see Stauch and Gualtieri, 2008), but, to date, no robust, region-wide, chronologicallyconstrained palaeoglacier reconstructions have been generated (cf. Velichko et al., 1984; Arkhipov et al., 1986; Zamoruyev, 2004; Glushkova, 2011). The lack of such reconstructions is not only of palaeoglaciological significance, but limits our understanding of the region's climatic history (see Felzer, 2001; Barr and Clark, 2011), prevents us from fully understanding former glacier-ocean-volcano interactions in the north Pacific (see Bigg et al., 2008; Nürnberg et al., 2011) and restricts our ability to test global, hemispheric and regional ice sheet models (e.g. Álvarez-Solas et al., 2011). This paper addresses this lack by reconstructing the extent of glaciers in Far NE Russia during the gLGM, and, to a lesser degree, during earlier phases of glaciation. This is achieved through comprehensive mapping the region's glacial geomorphology, and combining this record with a dataset of relevant published dates (that constrain the timing of former glaciation across the region). The significance of the record is discussed through consideration of palaeoclimatic forcing, and topographic controls upon glacier dimensions, dynamics, and moraine distribution, are also considered.

\section{Regional setting}

Far NE Russia, as defined here, comprises an area of almost 4 million $\mathrm{km}^{2}$, extending from the Lena River, in the west, to the Pacific coast, in the East (see figure 1). The region is dominated by a series of mountain chains, of which the highest (up to $4750 \mathrm{~m}$ above sea level; 
a.s.1.) are upon the Kamchatka Peninsula. Elsewhere, mountains rarely exceed $3000 \mathrm{~m}$ (a.s.1.), and are bounded by extensive lowlands, often scattered with thermokarst lakes. The region's climate is difficult to characterise, partly because of considerable spatial variability, but also because observations are sparse (Shahgedanova et al., 2002). Broadly-speaking, present-day winter climate is dominated by variations in the intensity of the Siberian High and Aleutian Low Pressure systems, while summer climate is regulated by a system of high pressure which develops over the North Pacific (Yanase and Abe-Ouchi, 2007). Interior regions are often extremely continental; characterised by aridity, cold winters and warm summers. In many regions, mean annual precipitation is consistently below $200 \mathrm{~mm}$, and the annual range in air temperatures has been found to exceed $100^{\circ} \mathrm{C}$ (Lydolph, 1977). The North Pacific and Okhotsk Sea serve as the region's principal sources of moisture, and coastal areas typically experience less extreme climatic conditions than the continental interior (Shahgedanova, 2002; Hijmans et al., 2005). Aridity in the far west of the region is also less extreme, as an Atlantic moisture-source results in mean annual precipitation in excess of $300 \mathrm{~mm}$ (Lydolph, 1977; Shahgedanova et al., 2002). These climate patterns are reflected, to some degree, in the distribution of modern glaciers, which are few in number, typically of cirque-type, restricted to the highest mountains, and cover a total area of only $\sim 1466 \mathrm{~km}^{2}$ (Zamoruyev, 2004; Ananicheva et al., 2008). The largest concentrations of glaciers are currently found within the Chersky Mountains, Koryak Highlands, and upon the Kamchatka Peninsula.

\section{Previous studies}

Field-based investigations of the glacial history of Far NE Russia have typically focused upon some of the region's most accessible locations (see Gualtieri et al., 2000; BrighamGrette et al., 2003; Stauch et al., 2007; Zech et al., 2011). These investigations have led to an improved understanding of the dimensions of former glaciers in specific regions, and have yielded a small number of geochronometric dates, with which to constrain former periods of glaciation (Gualtieri et al., 2000; Glushkova, 2001; Brigham-Grette et al., 2003; Laukhin et al., 2006; Stauch et al., 2007; Zech et al., 2011). These dating studies are discussed in section 5.2, and are synthesised, to some degree, by Stauch and Gualtieri (2008). To complement these field-based investigations, we have turned to a remote sensing approach, with Barr and Clark (2009) analysing satellite images to produce maps of end moraines across the region, and Barr and Clark (2011) utilising these maps and published age-estimates to produce reconstructions of glaciers in the Pacific sector of Far Easter Russia during the gLGM. 
Region-wide reconstructions of former glaciers in Far Eastern Russia are typically based upon limited geomorphological evidence (e.g. Velichko et al., 1984; Arkhipov et al. 1986; Grosswald, 1988; Grosswald and Hughes, 2002; Zamoruyev, 2004; Glushkova, 2011) or derived from numerical models, focusing upon much of the Northern Hemisphere (e.g. Budd et al, 1998; Calov and Marsiat, 1998; Bintanja et al., 2002; Álvarez-Solas et al., 2011), or models targeted at understanding glacier sensitivity to forcing, rather than specifically establishing former ice extent (e.g. Krinner et al., 2011). To date, published reconstructions vary significantly, and there remains little consensus about the former distribution of glaciers in Far Eastern Russia at the gLGM, or during other periods of Quaternary glaciation. The present paper addresses some of this uncertainty by combining detailed and comprehensive geomorphological mapping, analyses of topography, and all (known) published age-estimates which constrain former ice margins. As such, the reconstructions presented here are considered to reflect the extent of understanding, given all currently-available evidence.

\section{Methods}

\subsection{Mapping}

To establish the former extent of glaciation, remote sensing methods were used to map end moraines across the whole of Far NE Russia. Focus was placed upon end moraines (rather than other features), as they represent the most useful and easily-identifiable geomorphological indicators of former ice extent. Moraines were mapped from various data sources, including: Landsat 7 ETM+ satellite images; ASTER Global Digital Elevation Model (GDEM) version 2 data; and Viewfinder Panorama (VFP) DEM data (see table 1 for details). Moraines are ridge-like formations, asymmetric in cross section, with sallow proximal (up ice) and steep distal slopes, and often appear arcuate in plan-form (i.e. when viewed from satellite data). In the present study, they were identified on the basis of their morphology, topographic-context, surface-vegetation, association with other landforms, and their impact upon modern drainage (e.g. through damming lakes or diverting rivers). Satellite images were displayed as false colour composites of bands 5, $4 \& 2$ and panchromatic band 8 . The DEMs were displayed as semi-transparent shaded relief-images (with solar illumination from the NE, and a $45^{\circ}$ solar elevation), draped over a filled version of the data. Mapping was performed using a repeat-pass procedure, whereby each region was analysed on four separate occasions, at scales of 1:25,000; 1:50,000; 1:100,000; and 1:200,000. Features were manually-digitized on-screen by a single operator (IDB), and end moraines were mapped as 
polygon shapefiles, with emphasis placed upon outlining the break-of-slope around feature margins. Field-based ground-truthing was not performed, but mapping was partly verified through comparison with published sources (e.g. Laukhin, 1997; Glushkova, 1992, 2001; Gualtieri et al., 2000; Heiser and Roush, 2001; Laukhin et al., 2006).

\subsection{Reconstructing glacier dimensions}

Former ice margin positions were chronologically-constrained by compiling a dataset of relevant age-estimates from published sources. These are largely derived from glacial or glaciofluvial deposits (moraines and sediment sections), though part of the pre-gLGM chronology, upon the Kamchatka peninsula, is derived from marine sediment cores. The dimensions of ice masses during the gLGM were estimated by extrapolation from directlydated moraines, largely based upon moraine altitude and distance from mountain divides. Glacier margins were digitised in a Geographic Information System (GIS), with interconnecting lines drawn to connect mapped moraines. Though considered informative, it must be kept in mind that this reconstruction method is subjective, and is difficult to apply where geomorphological evidence is fragmentary or where dated moraines are lacking (such as the Kolyma-Anyuy region). As such, the reconstruction presented here might be considered a 'best-estimate' rather than a definitive representation of gLGM ice extent. Glacier margins during pre-gLGM phases were not outlined in detail, but the extent of glaciation was considered in some key (dated) localities.

\subsection{Topographic analyses}

In order to better understand topographic controls upon the distribution of moraines (i.e. to ascertain whether moraines cluster at specific altitudes or within particular topographic settings), the altitudinal-distribution of land surface area (hypsometry), land surface slope angles, and moraine density were analysed within different regions of Far NE Russia (regions were delineated on the basis of maps presented by Barr and Clark (2009)). These data were derived from the $\sim 30 \mathrm{~m}$ resolution ASTER GDEM, with an absolute vertical accuracy of $\sim 17$ m (ASTER GDEM Validation Team, 2011).

\section{Results}

\subsection{Mapped moraines}


A total of 8414 end moraines were identified and mapped across Far NE Russia. This compares to 2173 moraines mapped by Barr and Clark (2009) for this same region (using Landsat data alone, as the ASTER GDEM and VFP DEM datasets were unavailable at the time). It is not possible to produce detailed moraine maps within this paper, for reasons of page size and scale, but a general overview of moraine distribution is provided in figure $2 \mathrm{a}$ (and is considered in detail by Barr and Clark, submitted). Mapped moraines are found to cluster in, and around, the region's uplands, with multiple moraines identifiable within, or emanating from, many valleys (see figure 3). Moraines range in altitude from sea level to $1651 \mathrm{~m}$ (a.s.l), with some over $100 \mathrm{~m}$ in height, $82 \mathrm{~km}$ in length, and $16 \mathrm{~km}$ in width (see figure 3). Regional variations in moraine size (surface area) are evident (see figure 4), and may reflect variations in the dimensions of former glacier margins, the former availability of debris (geology), former ice-mass dynamics (velocity, mass-balance, thermal-regime), postdepositional erosion of moraines, and/or variations in the duration of glacial still-stands. The altitudinal-distribution of moraines also varies from region to region, and is likely governed by variations in palaeoclimate, land surface hypsometry and slope (see figure 4). This relationship is further considered in section 6.5.2.

\subsection{Dated moraines}

In order to establish the dimensions of glaciers in Far NE Russia during specific glacial periods, published age-estimates constraining the extent of former glaciation were compiled in a GIS (building upon the work of Stauch and Gualtieri., 2008) - with 25 dates of relevance found (see figure $2 \mathrm{~b}$ and table 2). To allow comparison with chronologies derived from cosmogenic and luminescence dating methods, all radiocarbon dates $(\mathrm{n}=8)$ were calibrated using the IntCal09 calibration curve (Reimer et al., 2009) and CALIB 6.1.0 program (Stuiver and Reimer, 1993, 2011). Therefore, all ages are hereafter reported in calendar years BP.

\section{Discussion}

The following discussion considers some of the interpretations which may be derived from the moraine record and chronology presented in this paper. First, the usefulness of the moraine record in general is considered; before an attempt is made to use this record to better understand the glacial and climatic history of Far NE Russia. Finally, some of the limitations of this approach are considered, with specific focus upon complexities introduced by topographic-controls upon glacier dimensions and moraine distribution. 


\subsection{Decoding the moraine record}

Moraine formation is mostly a consequence of sediment delivery to a stationary ice margin, whereby it accumulates to make such a landform. Large moraines therefore require stationary ice margins for some considerable time, and in inverse, once found can be used to infer glacial stillstands. The moraine record, presented in this paper, thus reflects the former position of glacier margins during various Late Quaternary glacial still-stands. However, decoding and extracting information from this record is a complex task. Glacial still-stands may be climatically or topographically controlled (see section 6.5), and occur following glacial advance, or as pauses during periods of net retreat. If all moraines reflected maximum ice extent following periods of advance, then the moraine record might be easily and directly linked to palaeoclimate, but to demonstrate that a moraine is a product of advance requires evidence of overridden material. In much of Far NE Russia, such evidence is lacking, due to limited field-based investigation, and moraines must be considered to reflect glacier margins either following a period of advance or during net retreat. In light of our inability to distinguish between these formation-mechanisms, in this paper, moraines are simply considered to reflect ice-margin positions, with no judgement as to whether ice margins reflect advanced positions or still-stands during retreat. This introduces complexity in attempting to extract a palaeoclimatic signal from the moraine record, and this must be kept in mind throughout the discussion which follows.

\subsection{The extent of former glaciation in Far NE Russia}

The distribution of moraines mapped in this study (see figure 2a) provides evidence that much of Far NE Russia was formerly glaciated (see figure 5a). The total glaciated-area is approximately $1,092,427 \mathrm{~km}^{2},(\sim 62 \%$ of the current area of the Greenland Ice Sheet $)$ and decreases from a maximum of $240,675 \mathrm{~km}^{2}$ upon the Chukchi Peninsula to a minimum of $145,463 \mathrm{~km}^{2}$ within the Kolyma-Anyuy Highlands (see figure 5). As indicated by Barr and Clark (2009), the clustering of moraines in, and around, the region's uplands, and their comparative absence on intervening lowlands, appears to indicate that former ice-masses in Far NE Russia were largely mountain-centred, rather than comprising a series of large and coalescing ice sheets which extended across the region (cf. Grosswald, 1998; Grosswald and Hughes, 2002). Much of the Pacific coastal sector of Far NE Russia was clearly once occupied by extensive ice masses (see figure 5a), which likely extended onto the, now 
submerged, continental shelf, and perhaps terminated in the North Pacific (see Bigg et al., 2008; Nürnberg et al., 2011). Inland, amongst the Kolyma and Chersky Mountains, former ice masses appear to have been less extensive, though the Verkhoyansk and Suntar-Khayata Mountains were once extensively-glaciated (see figure 5a).

\subsection{The extent of glaciation during the gLGM (MIS 2)}

In total, the database of published age-estimates (table 2) contains 17 of specific relevance to gLGM ice extent. When combined with the moraine record, this allows a 2D reconstruction of gLGM ice extent to be generated (see figure 5b). Though this reconstruction is both chronologically- and geomorphologically-constrained, it must be kept in mind that certainty regarding both the timing and extent of glaciation varies from region to region, as a function of both the availability of dates, and the completeness of the moraine record (the reconstruction is therefore considered a 'best estimate'). This reconstruction (figure $5 \mathrm{~b}$ ) clearly demonstrates that during the gLGM, ice masses bordering the Pacific Sector of Far NE Russia (i.e. in the Koryak Highlands and upon the Kamchatka Peninsula) were larger than those found further inland. In the Chukchi, Kolyma-Anyuy, Chersky and Suntar Khayata regions, glaciers were restricted to only the highest mountains, and rarely exceeded $40 \mathrm{~km}$ in length; whilst the Verkhoyansk Mountains appear to have remained largely glacier-free (see Stauch et al., 2007; Stauch and Gualtieri, 2008; Stauch and Lehmkuhl, 2010; Zech et al., 2011). This reconstruction indicates that during the gLGM, the total glacierised area of Far NE Russia was $\sim 253,000 \mathrm{~km}^{2}$ ( $\sim 14 \%$ of the current area of the Greenland Ice Sheet), with a general decrease in ice extent from the SE (Koryak and Kamchatka) to the north (Chukchi) and west (Kolyma-Anyuy, Suntar-Khayata, Chersky and Verkhoyansk)(see figure 6). This estimation of total glacierised area during the gLGM is considerably lower than estimates derived from many published reconstructions (even 'minimalist' depictions of gLGM ice extent). For example, the reconstruction presented by Zamoruyev (2004) suggests that an area of roughly $880,000 \mathrm{~km}^{2}$ was glacierised during the gLGM (figure 5c); whilst the reconstruction presented by Velichko et al. (1984) suggests an area of roughly $606,000 \mathrm{~km}^{2}$ was glacierised (figure 5d). The principal contrast between these published reconstructions and the one presented here is that the former suggest significant ice coverage in the Verkhoyansk Mountains during this period.

\subsection{Pre-gLGM ice extent}


There is strong evidence to suggest that across most (if not all) of Far NE Russia, glaciers attained their maximum Late Quaternary extent prior to the gLGM (MIS2)(see figures 6 and 7). This is evident from both the geomorphological and chronological record, though direct age-estimates for pre-gLGM ice margin positions are few. In total, the database of published age-estimate contains only 13 of direct use in constraining the pre-gLGM extent of glaciers (see table 2), and these cover the past $\sim 140 \mathrm{ka}$. This scarcity and temporal-distribution means that insufficient dates are available to generate region-wide reconstructions of pre-gLGM glaciers, and, instead, focus is placed upon areas where former ice margin positions have been chronologically-constrained by direct dating.

\subsubsection{Verkhoyansk Mountains}

In the Verkhoyansk Mountains, pre-gLGM moraine sequences have been dated in both the Tumara and Djanushka valleys (see figure 8). These records constrain ice margin positions at various periods during the past $\sim 140 \mathrm{ka}$ (see Stauch et al., 2007; Stauch and Lehmkuhl, 2010, 2011; Stauch and Gualitieri, 2008). Glaciers appear to have attained their maximum extent 140 ka (during MIS 6; see figure 7) —recorded by a terminal moraine in the Djanushka valley (moraine $\mathrm{V}$ in figure 8 ) and bracketed by infrared stimulated luminescence (IRSL) dates of $135 \pm 9 \mathrm{ka}$ and $141 \pm 10 \mathrm{ka}$ (Stauch et al., 2007). Subsequent phases of glaciation appear to have been successively less-extensive, and are recorded as a series of moraines (IVI) in the Tumara and Djanushka valleys (see figure 8). Moraine sequence IV is considered to have been deposited between 100 and $120 \mathrm{ka}$ (centered upon MIS 5d; see figure 7)(Stauch and Lehmkuhl, 2010), and is chronologically-constrained by IRSL dates of $97 \pm 6.8 \mathrm{ka}$ to $123 \pm 10 \mathrm{ka}$ from overlying deposits (Stauch et al., 2007), and $119 \pm 8 \mathrm{ka}$ for underlying lake sediments (Zech et al., 2011). Moraine sequence III has been chronologically-constrained by an IRSL date of $92.3 \pm 6.5 \mathrm{ka}$ from a sandy layer above a till and an IRSL age of $86.9 \pm 6.8$ ka from a glaciofluvial sand layer in between a till (Stauch et al., 2007). These dates indicate that the moraine was deposited during MIS 5b (as indicated by Stauch and Gualtieri, 2008; Stauch and Lehmkuhl, 2010), however, Stauch et al. (2007) are uncertain whether these samples underwent sufficient bleaching prior to deposition, and suggest that Moraine III was probably deposited during MIS 4. This is supported by Zech et al. (2011), who obtained an IRSL age of $79.1 \pm 5.5 \mathrm{ka}$ from sand deposits beneath a layer of till, and suggest moraine III was deposited after $\sim 78 \mathrm{ka}$. Moraine sequence II (see figure 8) was presumably deposited more recently than moraine sequence III (perhaps during late MIS 4; see figure 7), but has yet 
to be robustly dated (see Stauch et al., 2007). Finally, moraine sequence I is considered to have been deposited sometime prior to $50 \mathrm{ka}$, based upon an IRSL age-estimate of $52.8 \pm 4.1$ ka from upstream aeolian sediments within the Tumara Valley, and an IRSL age-estimate of $39.7 \pm 3.1 \mathrm{ka}$ from upstream aeolian sediments in the Djanushka River valley (see figure 8).

\subsubsection{Suntar-Khayata, Chersky, Moma, Kolyma and Anyuy Mountains}

In the Suntar-Khayata, Chersky, Moma, Kolyma and Anyuy Mountains, no deposits relating to pre-gLGM ice-margin positions have been directly-dated. However, the moraine record in this area clearly indicates that glaciers reached their maximum Quaternary extent (up to 270 $\mathrm{km}$ in the Suntar-Khayata Range) sometime prior to the gLGM (compare figures 5a and 5b). It is also apparent that, in comparison to the Verkhoyansk region, the moraine record is sparse, with very few moraines marking pre-gLGM ice margin positions (particularly in the northern Kolyma Mountains).

\subsubsection{Kamchatka Peninsula}

Upon the Kamchatka peninsula, the extent of glaciation prior to the gLGM is marked by a series of moraines which, in places, extend to the modern coastline (see figure 9). Direct onshore chronological-control upon pre-gLGM ice extent is limited to a site in SW Kamchatka, where a tephra layer from the Opala Volcano (c. 44 ka BP) is found overlying glacial deposits (Bäumler and Zech, 2000)(see figure 9). This tephra layer would appear to indicate that, in SW Kamchatka, glaciers have not extended beyond the modern coastline during the past $44 \mathrm{ka}$. However, Ice-rafted debris (IRD) records from the Okhotsk Sea (see Nürnberg et al., 2011) suggest glaciers in this discharged ice-bergs into the Okhotsk Sea at various periods during the past $140 \mathrm{ka}$, particularly during late MIS $6(\sim 138 \mathrm{ka}, \sim 135 \mathrm{ka}$, $\sim 129 \mathrm{ka}$, and $\sim 128 \mathrm{ka} \mathrm{BP}$ ) and MIS 3 ( 51 ka, 42 ka, 38 ka, 36 ka, and $\sim 31 \mathrm{ka})$. Some of these more recent dates are difficult to reconcile with the $\sim 44 \mathrm{ka}$ BP tephra layer identified by Bäumler and Zech (2000), and the suggestion that large Kamchatkan ice masses extended offshore as recently as $\sim 41-36 \mathrm{ka}$ BP is supported by IRD records from the NW Pacific (see Bigg et al., 2008).

\subsubsection{Koryak Highlands}

In the northern Koryak Highlands, the extent of glaciation during the gLGM is constrained by a series of in situ cosmogenic dates (see Gualtieri et al., 2000), and there is evidence that 
larger ice masses occupied this region prior to this period (see figure 10). Pre-gLGM icemargin positions have not been directly dated, but phases of advance are assumed to have occurred between perhaps 50 and 60 ka (early in MIS 3), and before (Gualtieri et al., 2000; Stauch and Gualtieri, 2008)(see figure 7). A cosmogenic date of 52.99 $\pm 4.1 \mathrm{ka}$ from a sample of exposed bedrock from Cape Dionysia (see sample 96CD13 in figure 10) reveals that this area has been glacier-free since at least this period.

\subsubsection{Chukchi Peninsula}

Upon the Chukchi Peninsula, a combined cosmogenic/radiocarbon chronology derived for moraines within the Pekulney Mountains and western sector of the Anadyr Lowlands (Brigham-Grette et al., 2003) has been used to constrain former ice extent during three distinct phases (see figures 7 and 11). The most recent occurred during the gLGM, with glaciers extending little more than $20 \mathrm{~km}$ in length (Barr and Clark, 2011). Earlier, perhaps $\sim 70 \mathrm{ka}$, glaciers appear to have extended $\sim 160 \mathrm{~km}$ in length - a chronology constrained by a direct age-estimate of $69.6 \pm 4.7 \mathrm{ka}$ from an outcrop of glacially-moulded bedrock (BrighamGrette et al., 2003) (see sample 95T34 in figure 11). There is also evidence that during the Middle Pleistocene or earlier (> $130 \mathrm{ka}$ )(Brigham-Grette et al., 2003)(see figure 11), glaciers were more extensive again, and perhaps attained lengths of $250 \mathrm{~km}$ (though no direct ageestimates have been obtained for moraines of this outer population). Upon the Vankarem Lowland (also part of the Chukchi Peninsula) a radiocarbon chronology established by Laukhin et al. (1989) appears to indicate three phases of advance since $\sim 45 \mathrm{ka}$, possibly in addition to gLGM glaciation (see figures 7 and 12). The moraine record in this region also preserves evidence of an earlier, more extensive phase, when glaciers extended to the modern Arctic coastline (see figure 12).

\subsubsection{Summary of Pre-gLGM ice extent}

Present understanding of ice extent across Far NE Russia during the past $\sim 160 \mathrm{ka}$ is summarised in figure 7. Though this record is incomplete (due to the scarcity of dates), it is apparent that former phases of glaciation were regionally-asynchronous. The moraine record in the Verkhoyansk Mountains is comparatively well-dated, and reveals at least five phases of pre-gLGM ice advance. In the Suntar-Khayata, Chersky and Moma (SKCM) Mountains, the moraine record reflects three distinct ice margin positions prior to gLGM, with glaciers up to $270 \mathrm{~km}$ in length. The timing of these phases remains unknown (due to a lack of direct- 
dating), and they are therefore excluded from figure 7. Similarly, in the Kolyma-Anyuy Highlands, the timing of pre-gLGM phases of glaciation remains unknown, but it is apparent that former ice-masses extended no further than $140 \mathrm{~km}$ in length. It also appears ice margin positions during fewer than three distinct phases are typically preserved by the moraine record here, and that in some regions, such as the northern Kolyma Mountains, evidence of only one period of former glaciation is recorded (and this is considered to reflect gLGM ice extent). Upon the Kamchatka Peninsula, the onshore record preserves evidence for at least one pre-gLGM phase of glaciation, and IRD deposits from the Okhotsk Sea indicate that glaciers extended beyond the modern coastline at various periods during the Late Quaternary (see Nürnberg et al., 2011). Finally, within the Koryak Highlands and upon the Chukchi Peninsula, there is evidence of at least two phases of glaciation prior to the gLGM, and synchronous glaciation of the Anadyr Lowlands and northern Koryak Mountains (see Gualtieri et al., 2000; Brigham-Grette et al., 2003; Stauch and Gualtieri, 2008. The pregLGM record of glaciation upon the Chukchi Peninsula is confused by dates obtained from the Vankarem Lowlands (Laukhin et al., 1989), which appear to suggest at least three phases of extensive $(>80 \mathrm{~km})$ glaciation during the past $44 \mathrm{ka}$. This timing is difficult to reconcile with the glacial record upon the Anadyr Lowland, though the moraine record here is particularly complex (see figure 3b), and ascertaining whether moraines reflect multiple, distinct phases of advance or were deposited during steady glacial retreat or minor re-advance is difficult to ascertain.

\subsection{Palaeoclimatic significance of the glacial record}

As outlined in the introduction to this discussion, linking the moraine record (dated or otherwise) to former glacial and/or climatic conditions in Far NE Russia is not a simple task. However, seemingly robust conclusions to emerge from both the chronological and geomorphological records are that: (i) the timing of glaciation in Far NE Russia is regionallyasynchronous, and (ii) glaciation in Far NE Russia is out-of-phase with other NorthernHemisphere regions (see Stauch and Gualtieri, 2008; Stauch and Lehmkuhl, 2010; Krinner et al., 2011; Zech et al., 2011)(see figure 7). These factors (particularly out-of-phase glaciation with other parts of the northern hemisphere) have led many to consider palaeoclimatic controls upon the former extent of glaciers in Far NE Russia (Laukhin et al., 2006; Stauch et al., 2007; Stauch and Gualtieri, 2008; Stauch and Lehmkuhl, 2010; Barr and Clark, 2011; Krinner et al., 2011; Zech et al., 2011). Three principal palaeoclimatic controls (moisture- 
availability, insolation, and albedo) are considered below, and this discussion builds upon a recent and detailed investigation by Krinner at al. (2011), where an atmosphere-only general circulation model (GCM) was used to evaluate the effect of variations in different forcing mechanisms upon the extent of former glaciation in Far NE Russia.

\subsubsection{Moisture availability}

The availability of palaeo-precipitation is widely-regarded to have been the dominant factor governing the extent and distribution of former ice-masses in Far NE Russia (see Laukhin et al., 2006; Stauch et al., 2007; Stauch and Gualtieri, 2008; Stauch and Lehmkuhl, 2010; Barr and Clark, 2011; Krinner et al., 2011). For example, the absence of glaciers in the Verkhoyansk Mountains during the gLGM has been attributed the region's severe aridity during this period, as westerlies from the North Atlantic were intercepted by the vast Eurasian ice sheets (Stauch and Gualtieri, 2008; Krinner et al., 2011; Sheinkman, 2011; Zech et al., 2011). Thus, the East - West reduction in the extent of glaciation across Far NE Russia during the gLGM (see figures $5 \mathrm{~b}$ and 6) might be attributed to a significant reduction in the supply of moisture from the Atlantic during this period, and the resulting dominance of the North Pacific as a moisture supply to much of the region (see fig 5 in Krinner et al., 2011). However, the supply of moisture from the North Pacific is also likely to have been reduced, as cooler sea-surface temperatures (Krinner et al., 2011), the exposure of vast areas of continental shelf (due to a global reduction in sea-level) and increased sea-ice extent and duration (Caissie et al., 2010) restricted evaporation during the gLGM, and ice-masses occupying coastal provinces (such as the Kamchatka Peninsula) acted as barriers to the inland advection of moisture-bearing air (see Barr and Clark, 2011). The impact of palaeoprecipitation upon former glaciation appears to extend back beyond the gLGM, with moisture-starvation due to the presence of ice sheets in Northern Europe and Western Russia considered the dominant factor restricting the development of large ice-masses in Far NE Russia over much of the Late Quaternary (Krinner et al., 2011). Figure 7 supports this assumption, as peaks in the volume of Eurasian ice sheets (at $\sim 18, \sim 60, \sim 88$, and $107 \mathrm{ka}$ ) roughly correspond to minima in the extent of glaciers in much of Far NE Russia. Given this apparent role of Eurasian ice sheets, attention is drawn to the possible influence imposed by former variations in the extent North American ice sheets. This was considered by Krinner et al. (2011) who conclude that North American ice extent is likely to impact upon glaciation in Far NE Russia, because of associated anomalies in atmospheric circulation (see Hoskins and 
Karoly, 1981). In fact, an ice sheet in North America during former periods of glaciation is likely to have had considerable impact upon ice extent globally, by causing a considerable reduction in global sea levels (compare volumes of the North American and Eurasian Ice Sheets in figure 7). However, the impact of a North American Ice Sheets upon the extent of glaciation in Far NE Russia is difficult to establish from figure 7, though, peaks in North American ice volume (at $\sim 20$ and $58 \mathrm{ka}$ ) roughly correspond with restricted glaciation in much of Far NE Russia.

\subsubsection{Insolation}

In addition to the role of moisture availability, Krinner et al. (2011), find regional summer temperatures (in their GCM simulations), and therefore glacier extent, to be governed (to a large degree) by insolation. Zech et al. (2011), focusing upon the Verkhoyansk Mountains, support this notion, and argue that phases of glaciation correspond with obliquity minima during MIS 6, 5d, and 4. July insolation over the past $160 \mathrm{ka}$, at $65^{\circ} \mathrm{N}$, is shown in figure 7 , and there is clearly some correspondence between this insolation record and former phases of glaciation in Far NE Russia (particularly in the Verkhoyansk Mountains and upon the Chukchi Peninsula); though this only appears to hold for certain periods.

\subsubsection{Reduced albedo}

Finally, Krinner et al. (2011), suggest that changes in vegetation distribution and dust deposition-rate are significant in determining the extent and timing of former glaciation in Far NE Russia. They propose that initial orbitally-induced cooling could be amplified by the expansion of tundra, and the associated increase in albedo, relative to taiga vegetation. They also suggest that extremely high dust deposition rates, and the associated reduction in albedo (when deposited upon snow or ice), are a potential cause of ice-free conditions in Far NE Russia during the gLGM (see Krinner et al., 2011). This remains a possibility, but is difficult to assess from the data presented in this paper.

\subsubsection{Summary of palaeoclimatic inferences derived from the glacial record}

There is strong evidence that periods of glaciation were out-of-phase with other regions of the Northern Hemisphere, where the development of ice sheets restricted the advection of moisture-bearing air masses to much of Far NE Russia, and resulted in a significant reduction in global sea levels. Thus, moisture availability appears to have been a dominant 
palaeoclimatic driver of glaciation in Far NE Russia, but other factors, including insolation, albedo and topography (see section 6.5) are also likely to have played a role.

\subsection{Topography as a confounding issue in regional palaeoclimate correlations}

Much of the discussion thus far has been concerned with linking the distribution of moraines, the former dimensions of glaciers, and palaeoclimate. However, topography also exerts a control upon glacier dimensions, dynamics, and moraine distribution, and is a confounding factor in attempting to make direct links with palaeoclimate. The following sections consider this topographic influence.

\subsubsection{Topographic controls upon glacier dimensions}

Glaciers advance and retreat in response to variations in mass-balance and internal-dynamics, but topography exerts a control upon resulting glacier-dimensions (see Sugden and John, 1976; Glasser et al., 2005; Kaplan et al., 2009). For example, the extent to which glaciers extend below the regional equilibrium-line altitude (ELA), where net annual accumulation and ablation are considered equal, is governed, to some degree, by the size of the glacier's accumulation (or catchment) area (found above the ELA). Glaciers with large accumulation areas can extend a considerable distance below the regional ELA, whereas glaciers with smaller accumulation areas experience limited ice flux through the ELA, and terminate a short distance below (see Benn and Evans, 2010). Thus, under uniform climatic conditions, glaciers occupying high mountains are likely to extend a considerable distance below the regional ELA, and the opposite is true of glaciers occupying more diminutive massifs (see figure 13a) (Andrews et al., 1970). In a similar manner, plateau and non-plateau topography can govern the size of a glacier's accumulation area, and therefore regulate overall dimensions. For example, in plateau environments, where a large land-surface area lies at high altitudes, the region of accumulation may be correspondingly large, and the flux of ice through the ELA is likely to be significant, allowing glaciers to extend a considerable distance below the ELA (see figure 13b). Thus, glacier dimensions are (at least to some degree) governed by topography, and it becomes difficult to extract a palaeoclimatic signal from the resulting moraine record. These topographic influences are difficult to isolate in many regions, but the complexity they introduce can be circumvented, to some degree, by producing 3D glacier reconstructions (using geomorphological or numerical methods), from which palaeo-ELA estimates (which take glacier hypsometry into consideration) may be 
derived (e.g. Barr and Clark, 2011). In cases where such 3D reconstructions have not been generated (as in the present study, and most others for Far NE Russia) direct links between the $2 \mathrm{D}$ distribution of glaciers and palaeoclimate should be made with acknowledgement of this uncertainty (and this applies to much of the discussion above).

\subsubsection{Topographic controls upon glacier dynamics, moraine deposition and preservation}

If moraines were deposited during climatically-driven glacial still-stands alone, and were not subdued to post-depositional modification, their distribution could be readily linked to palaeoclimate. However, moraines can be deposited during topographically (rather than climatically) controlled glacial still-stands (see Mercer, 1961; Funder 1972; Warren and Hulton, 1990), and their preservation can be regionally-variable (partly as a function of topography) (Putkonen and O’Neal, 2006). This relationship, between moraine distribution and topography, is illustrated in figure 4, where regional variations in land-surface hypsometry and land-surface slope angles, are considered alongside moraine density. The data illustrate a correspondence between these variables, as moraines cluster at, or near, hypsometric maxima (the altitudes at which the highest proportion of land surface area is found), and upon slopes with comparatively low surface gradients $\left(<15^{\circ}\right)$. This would give reason to believe that the distribution of moraines in Far NE Russia is, at least partly, controlled by topography, and we consider three hypotheses to potentially explain the relationships depicted in figure 4. However, it should be emphasised that the data presented here do not reflect a complete record of former ice margins in Far NE Russia, and this may limit our ability to make robust inter-regional comparisons. This is particularly true of the Kamchatka Peninsula, where some former glaciers terminated below the modern sea level, and are therefore excluded from the record considered here.

\section{i. Moraines are preferentially deposited at hypsometric maxima, where surface gradient is low}

Here, it is proposed that the moraine record strongly reflects topographically (rather than climatically) controlled glacial still-stands, which result in the clustering of moraines upon lowlands adjacent to upland valleys. The suggestion is that during periods of climaticallydriven advance, glaciers emerge from the topographic confines of narrow valleys, and extend laterally onto adjacent lowlands to form piedmont lobes (see example in figure 14a). This 
lateral extension results in a slowing of forward-advance and an increase in the glacier's ablation area. These factors, in combination, act to counter climatically-driven glacial advance, and for this reason, glaciers emerging from valley confines experience topographically-controlled still-stands, resulting in the deposition of 'piedmont moraines' (see figure 14b). It is hypothesised that this results in the clustering of moraines at the outlets of upland valleys (see Funder 1972; Warren and Hulton, 1990) — with 60\% of the moraines mapped within the present study found in roughly this context (see figure 4) - and explains the correspondence between hypsometric maxima, low surface slope angles, and moraine density, revealed in figure 4 (i.e. hypsometric maxima are considered to reflect piedmont regions, adjacent to mountain ranges). If this hypothesis holds, linking moraine distribution to palaeoclimate is likely to prove a very difficult task.

\section{ii. Moraines are preferentially preserved at hypsometric maxima, where surface gradient is low}

The moraine record presented in this paper reflects former glacier extent and dynamics, but also regional variations in moraine preservation. The absence of moraines from the record may well reflect formerly ice-free conditions, but may also indicate significant postdepositional landform modification (erosion and weathering). Such processes are known to hamper moraine identification, and to vary spatially, as a function of climate, time since landform deposition, and land-surface slope (Putkonen and O’Neal, 2006). This latter factor may well explain the apparent clustering of moraines at hypsometric maxima (figure 4), as such areas coincide with low surface slopes angles (i.e. moraines on steeper slopes have been eroded). However, though post-depositional modification undoubtedly has some influence upon moraine identification, we consider this an unlikely explanation for the relationship depicted in figure 4, at least partly because of the considerable size of moraines mapped within this study, i.e. large moraines are likely to have been partially-eroded and segmented (see example in figure $8 \mathrm{~b}$ ), rather than being entirely removed from the record.

\section{iii. The relationship between topography and moraine-distribution reflects the action of a 'glacial buzzsaw'}

The final hypothesis considered here is that figure 4, rather than reflecting topographic control upon former glacier dimensions, dynamics or moraine preservation, in fact reflects glaciological control upon land surface hypsometry and slope. This relates to the 'glacial 
buzzsaw' hypothesis, which states that glacial erosion is most intense at, or close to, the ELA, and there is therefore a concentration of land surface topography (hypsometric maximum), and shallow land-surface slopes at this altitude (see Brozović et al., 1997; Foster et al., 2008; Egholm et al., 2009). In light of this 'glacial buzzsaw' hypothesis, hypsometric maxima in figure 4 might be considered analogues for ELA (modern and palaeo), and regional variations in the altitude of these maxima may reflect climatically-driven ELA variations. However, Egholm et al. (2009), through a global analysis of topography and using a landscapeevolution model, found hypsometric maxima to fall just below the modern snowline (roughly coincident to the ELA), and above the LGM snowline. Thus the concentration of moraines at the hypsometric maxima, rather than below this point (as would be expected if hypsometric maxima lie between modern and palaeo snowlines) might bring the 'glacial buzzsaw' hypothesis into question as an explanation for the distribution of moraines in Far NE Russia.

\subsubsection{Summary of topography as a confounding issue in regional climate correlations}

It is clear, based upon the discussion above, that topographic controls upon the moraine record in Far NE Russia are likely to restrict our ability to derive robust palaeoclimatic data from the glacier reconstructions presented in this paper. At present, given the lack of fieldbased investigation, the geomorphological and topographic records alone offer no clear solution to this problem, and without further investigation (including further dating of glacial deposits), climatic and topographic controls upon the moraine record are difficult to isolate. A potential solution might be to implement further numerical modelling of former ice masses, as future model simulations may be tested against the moraine record provided here.

\section{Conclusions}

The distribution of moraines across the whole of Far NE Russia has been mapped from numerous moderate-to-high resolution remote sensing sources, and this moraine record has been combined with a dataset of published age-estimates, used to ascertain the timing of former glaciation across the region. From these data (moraines and dates) the extent of glaciation during the gLGM (MIS 2), and during earlier phases of glaciation is reconstructed. Palaeoclimatic and topographic controls upon palaeoglacier dimensions, dynamics, and the distribution of moraines are also considered. The following conclusions can be drawn from this investigation: 
1. Moraines are distributed throughout upland regions of Far NE Russia, and reflect the former presence of mountain-centred ice-masses

2. The geomorphological record reveals that much of Far NE Russia $\left(\sim 1,092,427 \mathrm{~km}^{2}\right)$ preserves a glaciated landscape, but there is no onshore evidence of glaciers having extended more than $270 \mathrm{~km}$ beyond mountain centres. This argues against widespread, lowland glaciation of the region by large ice sheets (as proposed by Grosswald, 1998; Grosswald and Hughes, 2002).

3. The timing of former glaciation in Far NE Russia appears to have been regionallyasynchronous, and out-of-phase with glaciations elsewhere in the Northern Hemisphere (see figure 7).

4. During the gLGM, glaciers occupied $\sim 253,000 \mathrm{~km}^{2}$, but rarely extended beyond 50 $\mathrm{km}$ in length

5. In most (if not all) regions, glaciers attained their maximum Late Quaternary extent prior to the gLGM (MIS2), and in places extended to, and perhaps beyond, the modern coastline.

6. The distribution of moraines in Far NE Russia is considered to reflect a complex signal of palaeoclimatic and topographic controls upon former glacier dimensions, dynamics, and moraine preservation.

\section{Acknowledgments}

We thank Ola Fredin and an anonymous reviewer for helpful comments that improved this manuscript. 


\section{References}

Álvarez-Solas, J., Montoya, M., Ritz, C., Ramstein, G., Charbit, S., Dumas, C., Nisancioglu, K., Dokken, T., Ganopolski,, A. 2011. Heinrich event 1: an example of dynamical ice-sheet reaction to oceanic changes. Climate of the Past, 7, 1297-1306.

Ananicheva, M.D., Krenke, A.N., Hanna, E., 2008. Mountain glaciers of NE Asia in the near future: a projection based on climate-glacier systems interaction. The Cryosphere Discussions, $2,1-21$.

Andrews, J.T., Barry, R.G., Draper, L., 1970. An inventory of the present and past glacierization of Home Bay and Okoa Bay, east Baffin Island, NWT, Canada, and some climatic and palaeoclimatic considerations. Journal of Glaciology, 57, 337-362.

Arkhipov, S.A., Bespaly, V.G., Faustova, M.A., Glushkova, O.Yu., Isaeva, L.L., Velichko, A.A., 1986. Glaciation of Siberia and North-east USSR. Quaternary Science Reviews, 5, 463474.

ASTER GDEM Validation Team. 2011. ASTER Global Digital Elevation Model Version 2 Summary of Validation Results.

Barr, I.D., 2009. Constraining the extent, style and phases of glaciation to derive Late Quaternary equilibrium-line altitude estimates in Far NE Russia. Ph.D. Thesis, University of Sheffield, UK.

Barr, I.D., Clark, C.D., 2009. Distribution and pattern of moraines in Far NE Russia reveal former glacial extent. Journal of Maps, 2009, 186-193.

Barr, I.D., Clark, C.D., 2011. Glaciers and climate in Pacific Far NE Russia during the Last Glacial Maximum. Journal of Quaternary Science, 26(2), 227-237. 
Barr, I.D., Clark, C.D., submitted. An updated moraine map of Far NE Russia. Journal of Maps.

Bäumler, R., Zech, W., 2000. Quaternary paleosols, tephra deposits and landscape history in South Kamchatka, Russia. Catena, 41, 199-215.

Benn, D.I., Evans, D.J.A., 2010. Glaciers \& Glaciation. Hodder Education, London.

Berger, A., Loutre, M.F., 1991. Insolation values for the climate of the last 10 million years. Quaternary Science Reviews, 10, 297-317.

Bigg, G.R., Clark, C.D., Hughes, A.L.C., 2008. A last glacial ice sheet on the Pacific Russian coast and catastrophic change arising from coupled ice-volcanic interaction. Earth and Planetary Science Letters, 265, 559-570.

Bintanja, R., van der Wal, R.S.W., Oerlemans, J., 2002. Global ice volume variations through the last glacial cycle simulated by a 3-D ice-dynamic model. Quaternary International, 95/96, $11-23$.

Brigham-Grette, J., Gualtieri, L.M., Glushkova, O.Y., Hamilton, D.M., Kotov, A., 2003. Chlorine-36 and ${ }^{14} \mathrm{C}$ chronology support a limited last glacial maximum across central Chukotka, northeastern Siberia, and no Beringian ice sheet. Quaternary Research, 59, 386398.

Brozović, N., Burbank, D.W., Meigs, A.J., 1997. Climatic Limits on Landscape Development in the Northwestern Himalaya. Science, 276, 571-574.

Budd, W.F., Courts, B., Warner, R.C., 1998. Modelling of the Antarctic and the Northern Hemisphere ice sheet changes with global climate through the glacial cycle. Annals of Glaciology, 27, 153-160. 
Caissie BE, Brigham-Grette J, Lawrence KT, Herbert TD, Cook MS. 2010. Last Glacial Maximum to Holocene Sea Surface Condition at Umnak Plateau, Bering Sea as inferred from Diatom, Alkenone, and Stable Isotope Records. Paleoceanography 25, PA1206,.

Calov, R., Marsiat, I., 1998. Simulations of the Northern Hemisphere through the last glacialinterglacial cycle with a vertically integrated and a three-dimensional thermomechanical icesheet model coupled to a climate model. Annals of Glaciology, 27, 169-176.

de Ferranti, J., 2010. Viewfinder panoramas.

Available online at: www.viewfinderpanoramas.org (accessed 01/06/2011).

Egholm, D.L., Nielsen, S.B., Pedersen, V.K., Lesemann, J. 2009, Glacial effects limiting mountain height. Nature, 460, 884-887.

Foster, D., Brocklehurst, S.H., Gawthorpe, R.L., 2008. Small valley glaciers and the effectiveness of the glacial buzzsaw in the northern Basin and Range, USA. Geomorphology, 102, 624-639.

Felzer, B., 2001. Climate impacts of an ice sheet in East Siberia during the Last Glacial Maximum. Quaternary Science Reviews, 20, 437-447.

Funder, S., 1972. Deglaciation of the Scoresby Sund fjord region, northeast Greenland. In: Sugden, D.E., Price, R.J., (Eds.), Polar geomorphology, Institute of British Geographers, Special publication, London, pp. 33-42.

GEBCO: General Bathymetric Chart of the Ocean, 2009. Hosted by the British Oceanographic Data Centre (BODC). http://www.gebco.net

Glasser, N.F., Jansson, K.N., Harrison, S., Rivera, A., 2005. Geomorphological evidence for variations of the North Patagonian Icefield during the Holocene. Geomorphology, 71, 263277. 
Glushkova, O.Y., 1992. Paleogeography of Late Pleistocene Glaciation of North-Eastern Asia. Proceedings of the International Conference of Arctic Margins. Russian Academy of Sciences, Far East Branch, Northeast Science Center, Magadan, pp. 339-344.

Glushkova, O.Y., 2001. Geomorphological correlation of Late Pleistocene glacial complexes of Western and Eastern Beringia. Quaternary Science Reviews, 20, 405-417.

Glushkova, O.Y., 2011. Late Pleistocene Glaciations in North-East Asia. In: Ehlers, J., Gibbard, P. L., Hughes, P.D. (Eds.), Quaternary Glaciations - Extent and Chronology, Part IV - A Closer Look. Elsevier, Amsterdam, pp. 865-875.

Grosswald, M.G., 1988. An Antarctic-style ice sheet in the Northern Hemisphere: Toward the new global glacial theory. Polar Geography, 12 (4), 239-267.

Grosswald, M.G., 1998. Late-Weichselian ice sheets in Arctic and Pacific Siberia. Quaternary International, 45/46, 3-18.

Grosswald, M.G., Hughes, T.J., 2002. The Russian component of an Arctic Ice Sheet during the Last Glacial Maximum. Quaternary Science Reviews, 21, 121-146.

Gualtieri, L., Glushkova, O., Brigham-Grette, J., 2000. Evidence for restricted ice extent during the last glacial maximum in the Koryak Mountains of Chukotka, far eastern Russia. Geological Society of America Bulletin, 112, 1106-1118.

Heiser, P.A., Roush, J.J., 2001. Pleistocene glaciations in Chukotka, Russia: moraine mapping using satellite synthetic aperture radar (SAR) imagery. Quaternary Science Reviews, 20, 393-404.

Hijmans, R.J., Cameron, S.E., Parra, J.L., Jones, P.G., Jarvis, A., 2005. Very High Resolution Interpolated Climate Surfaces for Global Land Area. International Journal of Climatology, 25: 1965-1978. 
Hoskins, B.J., Karoly, D.J., 1981. The steady linear response of a spherical atmosphere to thermal and orographic forcing. Journal of Atmospheric Science, 38, 1179-1196.

Kaplan, M.R., Hein, A.S., Hubbard, A., Lax, S.M., 2009. Can glacial erosion limit the extent of glaciation? Geomorphology, 103, 172-179.

Krinner, G., Diekmann, B., Colleoni, F., Stauch, G., 2011. Global, regional and local scale factors determining glaciation extent in Eastern Siberia over the last 140,000 years. Quaternary Science Reviews, 30, 821-831.

Laukhin, S.A., 1997. The Late Pleistocene glaciation in the northern Chukchi Peninsula. Quaternary International, 41/42, 33-41.

Laukhin, S.A., Drozdov, N.I., Panychev, V.A., Velichko, S.V., 1989. The data on the Last Glaciation in northern East Chukotka. International Geology Review, 31, 527-531.

Laukhin, S.A., Zhimin, J., Pushkar, V.S., Cherepanova, M.V., 2006. Last Glaciation in the Northern Part of the Eastern Chukchi Peninsula and Paleoceanography of the North Pacific. Doklady Earth Sciences, 411A (9), 1422-1426.

Lydolph, P.E., 1977. Climates of the Soviet Union. World Survey of Climatology 7. Elsevier, Amsterdam.

Marshall, S.J., James, T.S., Clarke, G.K.C., 2002. North American Ice Sheet reconstructions at the Last Glacial Maximum. Quaternary Science Reviews, 21, 175-192.

Mercer, J.H., 1961. The response of fjord glaciers to changes in the firn limit. Journal of Glaciology, 3, 850-858.

Nürnberg, D., Dethleff, D., Tiedemann, R., Kaiser, A., Gorbarenko, S., 2011. Okhotsk Sea ice coverage and Kamchatka glaciation over the last $350 \mathrm{ka}$-Evidence from ice-rafted debris and planktonic $\delta^{18}$ O. Palaeogeography, Palaeoclimatology, Palaeoecology, 310, 191205. 
Putkonen, J., O’Neal, M., 2006. Degradation of unconsolidated Quaternary landforms in the western North America. Geomorphology, 75, 408-419.

Reimer, P.J., Baillie, M.G.L., Bard, E., Bayliss, A., Beck, J.W., Blackwell, P.G., Bronk Ramsey, C., Buck, C.E., Burr, G.S., Edwards, R.L., Friedrich, M., Grootes, P.M., Guilderson, T.P., Hajdas, I., Heaton, T.J., Hogg, A.G., Hughen, K.A., Kaiser, K.F., Kromer, B., McCormac, F.G., Manning, S.W., Reimer, R.W., Richards, D.A., Southon, J.R., Talamo, S., Turney, C.S.M., van der Plicht, J., Weyhenmeyer, C.E., 2009. IntCal09 and Marine09 radiocarbon age calibration curves, 0-50,000 years cal BP. Radiocarbon 51(4), 1111-1150.

Shahgedanova, M., Perov, V., Mudrov, Y., 2002. The Mountains of Northern Russia. In: Shahgedanova, M. (Ed.), The Physical Geography of Northern Eurasia. Oxford University Press, Oxford, pp. 284-313.

Sheinkman, V.S., 2011. Glaciation in the High Mountains of Siberia. In: Ehlers, J., Gibbard, P. L., Hughes, P.D. (Eds.), Quaternary Glaciations - Extent and Chronology, Part IV - A Closer Look. Elsevier, Amsterdam, pp. 883-907.

Siegert, M.J., Dowdeswell, J.A., Hald, M., Svendsen, J.I., 2001. Modelling the Eurasian Ice Sheet through a full (Weichselian) glacial cycle. Global and Planetary Change, 31, 367-385.

Siegert, M.J., Marsiat, I., 2001. Numerical reconstructions of LGM climate across the Eurasian Arctic. Quaternary Science Reviews, 20, 1595-1605.

Stauch, G., Gualtieri, L., 2008. Late Quaternary glaciations in northeastern Russia. Journal of Quaternary Science, 23, 545-558.

Stauch, G., Lehmkuhl, F., 2010. Quaternary glaciations in the Verkhoyansk Mountains, Northeast Siberia. Quaternary Research, 74, 145-155.

Stauch, G., Lehmkuhl, F., 2011. Extent and Timing of Quaternary Glaciations in the Verkhoyansk Mountains. In: Ehlers, J., Gibbard, P. L., Hughes, P.D. (Eds.), Quaternary 
Glaciations - Extent and Chronology, Part IV - A Closer Look. Elsevier, Amsterdam, pp. 877881.

Stauch, G., Lehmkuhl, F., Frechen, M., 2007. Luminescence chronology from the Verkhoyansk Mountains (North-Eastern Siberia). Quaternary Geochronology, 2, 255-259.

Stuiver, M., Reimer, P.J., 1993. Extended ${ }^{14} \mathrm{C}$ data base and revised CALIB $3.0{ }^{14} \mathrm{C}$ age calibration program. Radiocarbon, 35, 215-230.

Stuiver, M., Reimer, P.J., 2011. CALIB 6.1.0. http://calib.qub.ac.uk/calib/

Sugden, D.E., John, B.S., 1976. Glaciers and Landscape. Glaciers and Landscape, Edward Arnold, London.

Svendsen, J.I., Alexanderson, H., Astakhov, V.I., Demidov, I., Dowdeswell, J.A., Funder, S., Gataullin, V., Henriksen, M., Hjort, C., Houmark-Nielsen, M., Hubberten, H., Ingólfsson, O., Jakobsson, M., Kjær, K., Larsen, E., Lokrantz, H., Lunkka, J.P., Lyså, A., Mangerud, J., Matiouchkov, A., Möller, P., Murray, A., Niessen, F., Nikolskaya, O., Polyak, P., Saarnisto, M., Siegert, C., Siegert, M.J., Spielhagen, R.F., Stein, R., 2004. Late Quaternary ice sheet history of Northern Eurasia. Quaternary Science Reviews. 23, 1229-1271.

Velichko, A.A., Isayeva, L.L., Makeyev, V.M., Matishov, G.G. and Faustova, M.A. 1984. Late Pleistocene Glaciation of the Arctic Shelf, and the Reconstruction of Eurasian Ice Sheets. In: Velichko, A.A. (Ed.) Late Quaternary Environments of the Soviet Union. Longman, London, pp.35-41.

Warren, C.R., Hulton, N.R.J., 1990. Topographic and glaciological controls on Holocene icesheet margin dynamics, central west Greenland. Annals of Glaciology, 14, 307-310.

Yanase, W., Abe-Ouchi, A., 2007. The LGM surface climate and atmospheric circulation over East Asia and the North Pacific in the PMIP2 coupled simulations. Climate of the Past, 3, $439-451$. 
Zamoruyev, V., 2004. Quaternary glaciation of north-eastern Asia. In: Ehlers, J., Gibbard, P. L. (Eds.), Quaternary Glaciations - Extent and Chronology, Part III: South America, Asia, Africa, Australia, Antarctica. Elsevier, Amsterdam, pp. 321-323.

Zech, W., Zech, R., Zech, M., Leiber, K., Dippold, M., Frechen, M., Bussert, R., Andreev, A., 2011. Obliquity forcing of Quaternary glaciation and environmental changes in NE Siberia. Quaternary International, 234 , $133-145$ 


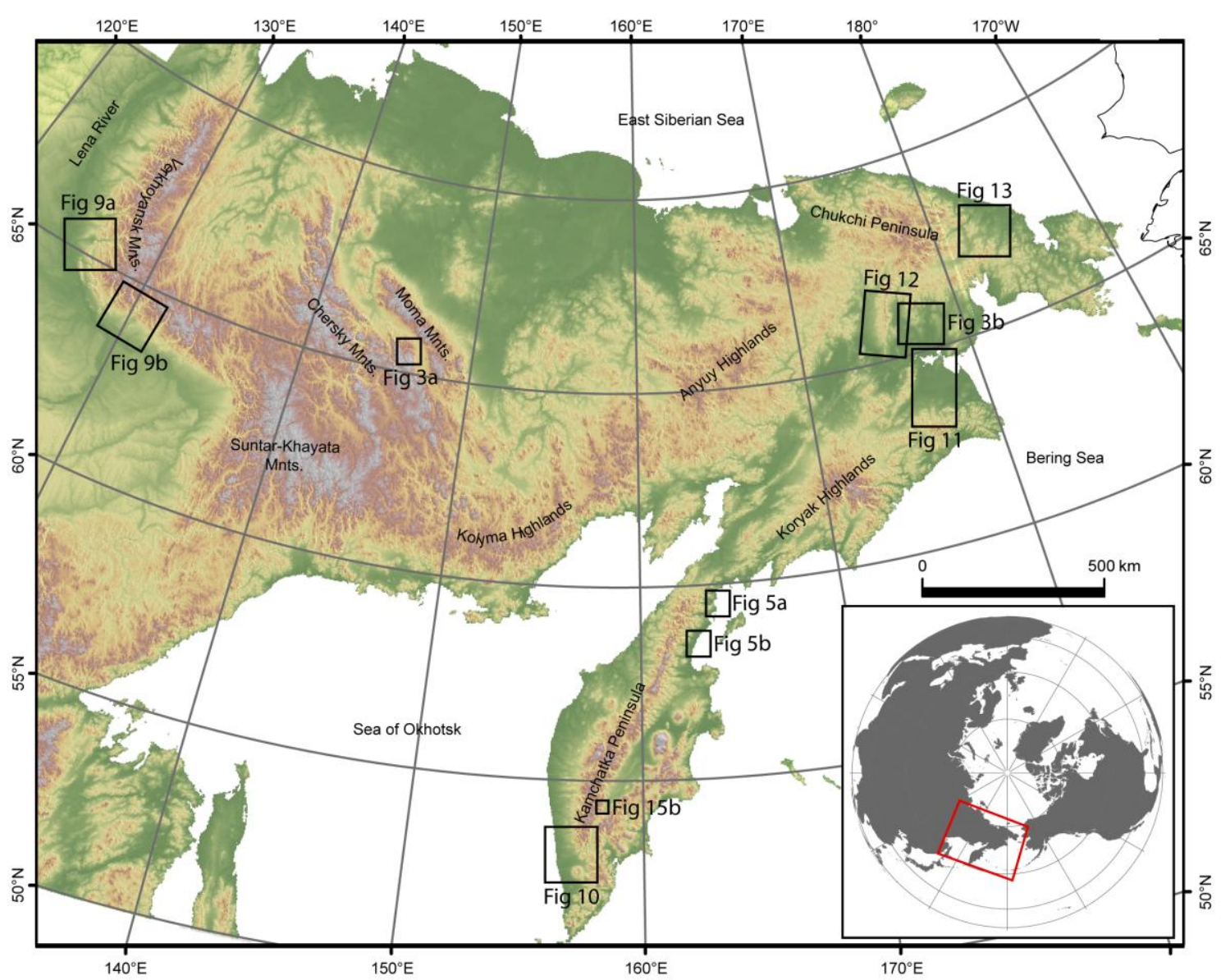

Figure 1. Far NE Russia and its principal topographic regions. Boxed areas refer to figures shown in this paper. 

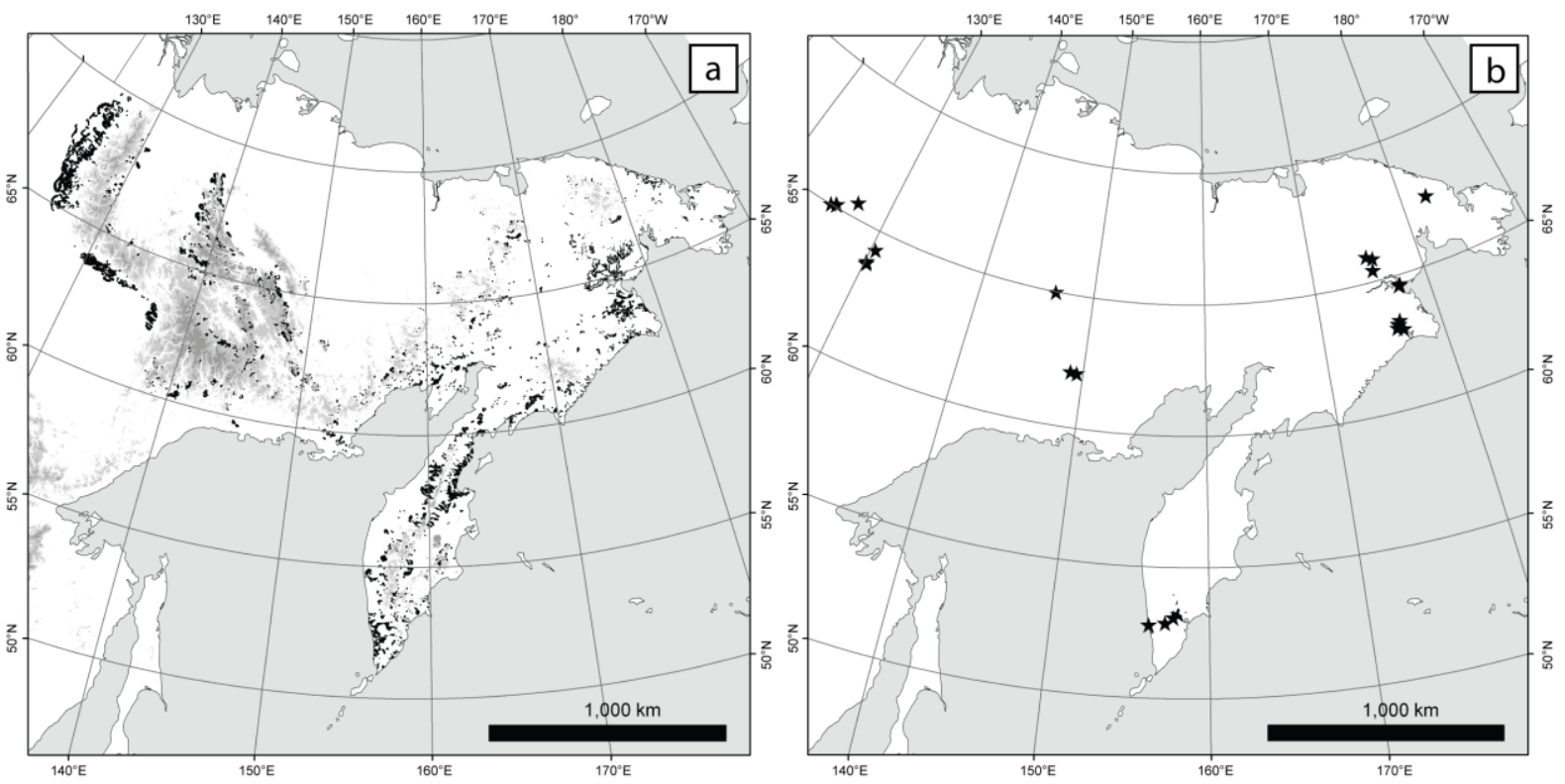

Figure 2. (a) End moraines (black), as mapped across Far NE Russia ( $=8414)$. (b) Site locations (depicted as stars) where dated samples serve to constrain the extent of former glaciation (see table 2 for specific details). For some sites, more than one date is recorded. Shaded regions reflect land above $1000 \mathrm{~m}$ (a.s.1.). 

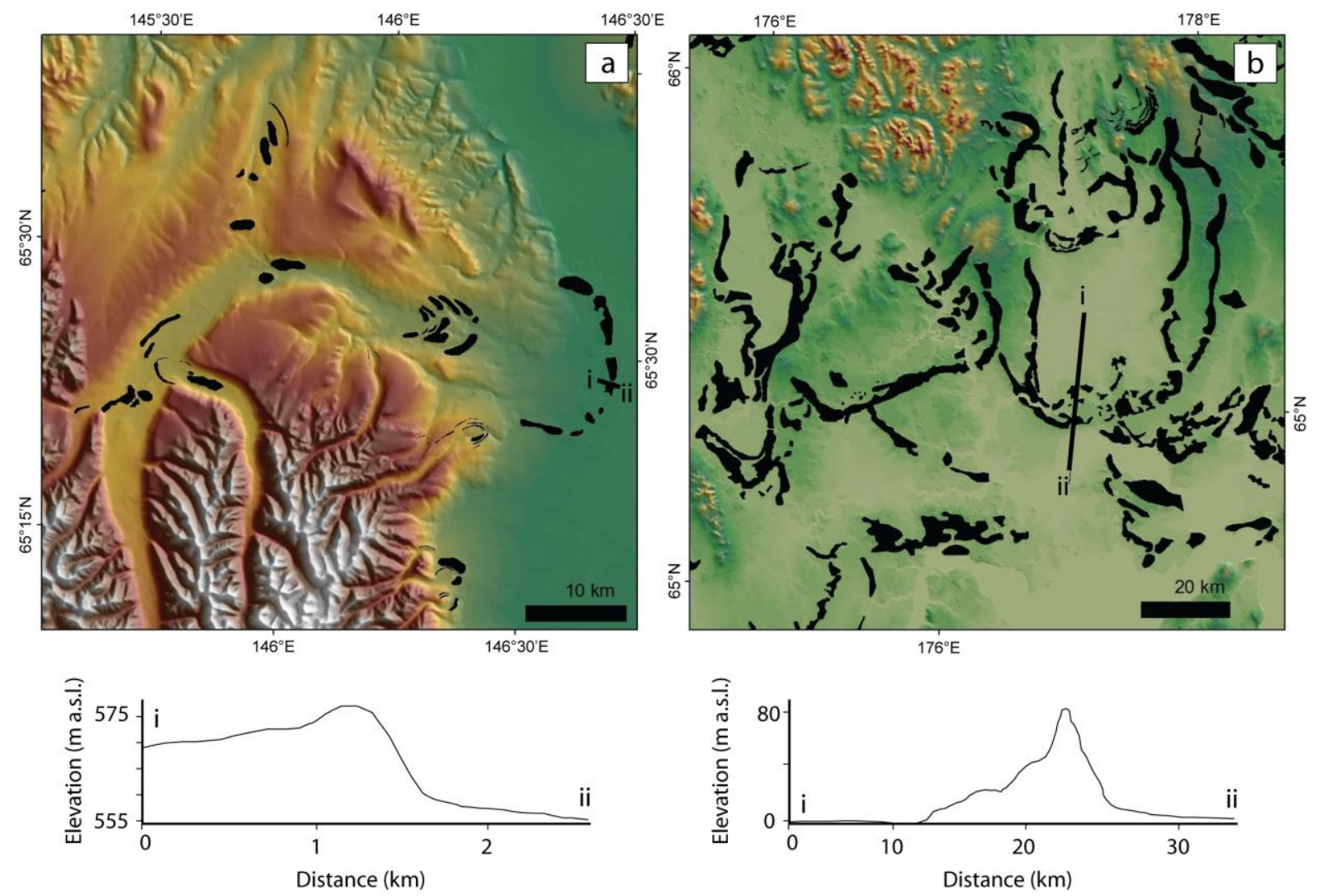

Figure 3. Mapped moraines (black), and selected cross-sections (derived from VFP DEM data). (a) In the central Chersky mountains. (b) Upon the Anadyr Lowlands of the Chukchi Peninsula. These examples illustrate that many valleys contain multiple moraines, and some of the largest moraines are up to $100 \mathrm{~m}$ in height. See figure 1 for site locations. 


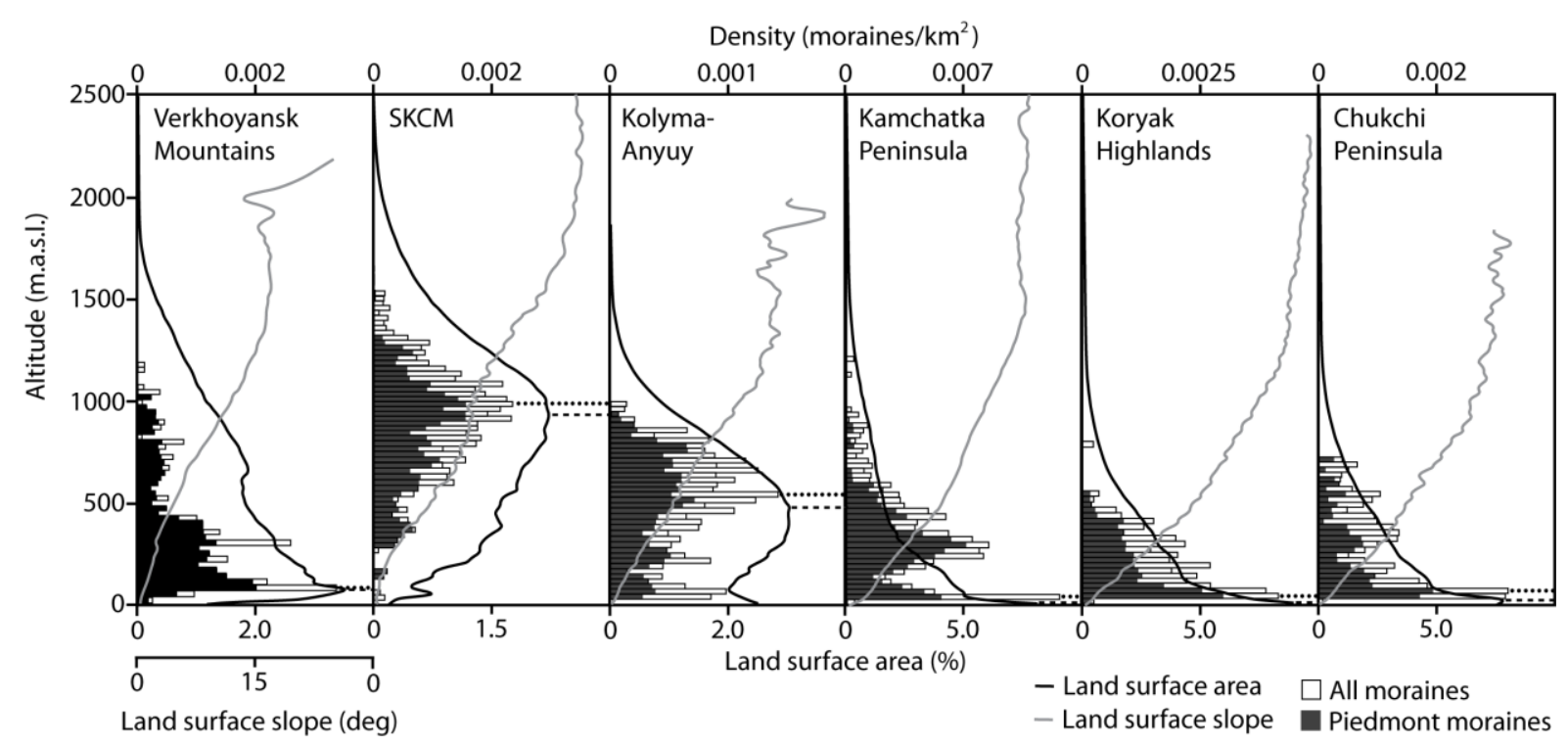

Figure 4. Land-surface hypsometry (area with altitude), and slope-elevation profiles for the different regions of Far NE Russia; plotted alongside moraine density-with-altitude for each of these regions (shaded bars correspond to piedmont moraines, see section 6.5.2). Data are grouped into $25 \mathrm{~m}$ altitude bins. The horizontal dashed lines correspond to the hypsometric maxima (the altitudes at which the highest proportion of land surface area is found) for each region. These hypsometric maxima vary from region-to-region, and appear to correspond with moraine density maxima (horizontal dotted lines). This image highlights the relationship between moraine distribution and regional topography (note how the moraines mostly follow the shape and position of the hypsometric curve). 

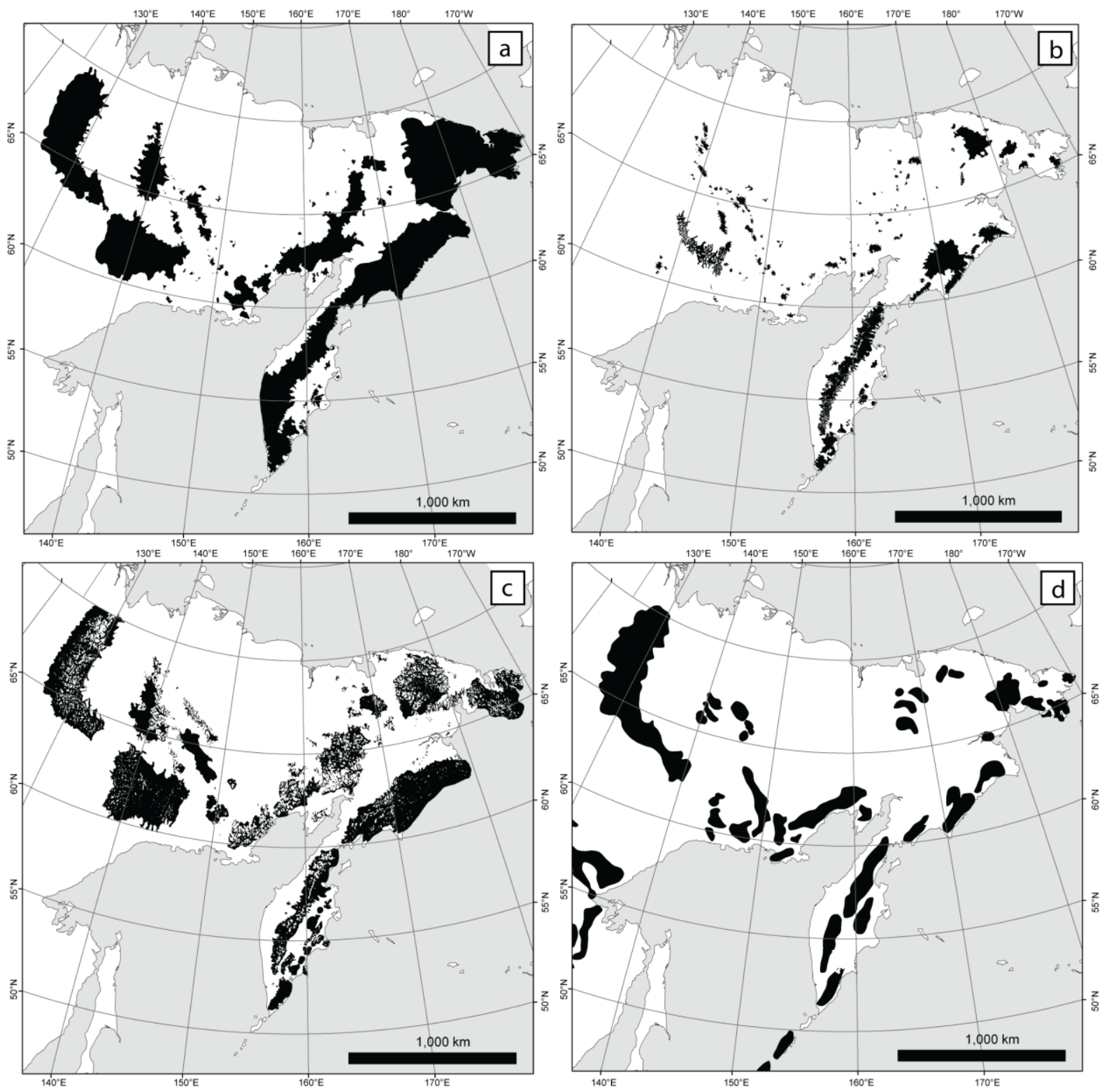

Figure 5. (a) Region (in black) of Far NE Russia lying within the limits of mapped moraines and/or characterised by a glacially-eroded landscape (u-shaped valleys), and interpreted as the Quaternary maximum extent .(b) A chronologically- and geomorphologically-constrained reconstruction of glaciation across Far NE Russia during the global Last Glacial Maximum (gLGM)(area shown in black). (c) LGM ice extent in Far NE Russia, as depicted by Zamoruyev (2004). (d) Approximate LGM ice extent in Far NE Russia, as depicted by Velichko et al (1984) (image redrawn from original publication). 


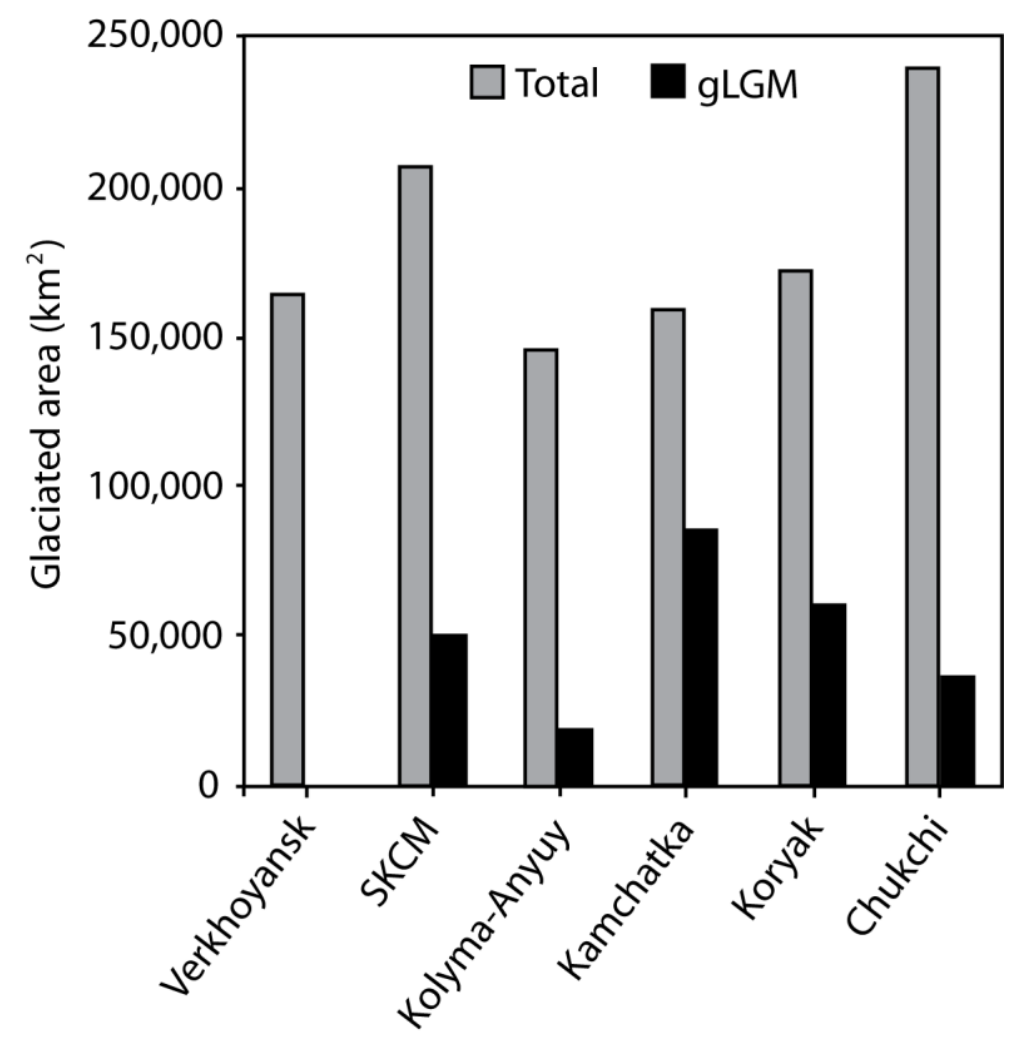

Figure 6. Regional variations in the total glaciated-area of Far NE Russia (grey) and the glaciated area during the global Last Glacial Maximum (gLGM)(black). This illustrates that, in each of these regions, gLGM ice-masses were considerably less extensive that during earlier phases of glaciation. The figure also highlights a general East-West decrease in ice extent during the gLGM, potentially reflecting a precipitation gradient extending inland from the North Pacific. 


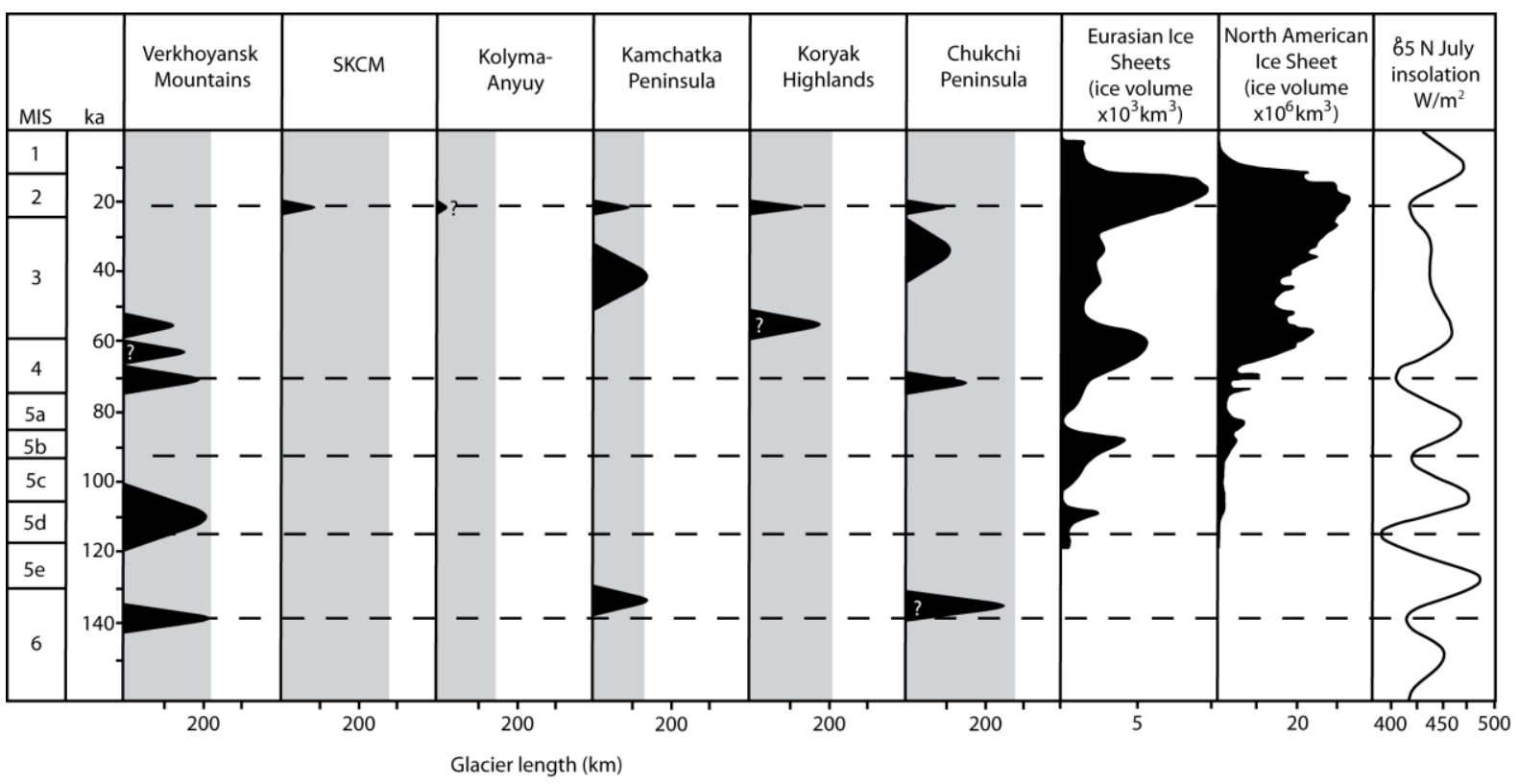

Figure 7. Variations in the extent of glaciers in different regions of Far NE Russia over the past $160 \mathrm{ka}$ (see sections 6.3.1 to 6.3 .6 for details). Glacier length is estimated from the moraine record (see figure 2a), and published age-estimates are used to chronologically constrain former ice-margin positions (see table 2). The shaded grey area reflects the maximum extent of glaciation recorded by the moraine record in each region. It is apparent, that in some regions the timing of this maximum ice-extent is unknown (e.g. in the KolymaAnyuy region), and upon the Kamchatka Peninsula there is evidence for glaciers having extended beyond the margins defined by the onshore moraine record (i.e. glaciers were formerly marine-terminating, and therefore extended beyond the shaded grey area shown here). The '?' symbol denotes phases of glaciation lacking chronological-control. Also shown are curves depicting modelled volumes of the Eurasian (Scandinavian, British and BarentsKara) ice sheets (redrawn from Svendsen et al., 2004; based upon Siegert et al., 2001) and North American Ice Sheet (redrawn from Marshall et al., 2002). Comparison with these Eurasian and North American ice sheets emphasises how the timing of former glaciation in Far NE Russia is out-of-phase with much of the northern Hemisphere. To the far right is midJuly insolation at $65^{\circ} \mathrm{N}$ over this period (data from Berger and Loutre, 1991). Dashed horizontal lines correspond to insolation minima. Image based on a version by Stauch and Gualtieri (2008).This figure is not a complete record of former glaciation in these regions over the past $160 \mathrm{ka}$, but is an interpretation considered to reflect currently available evidence. 

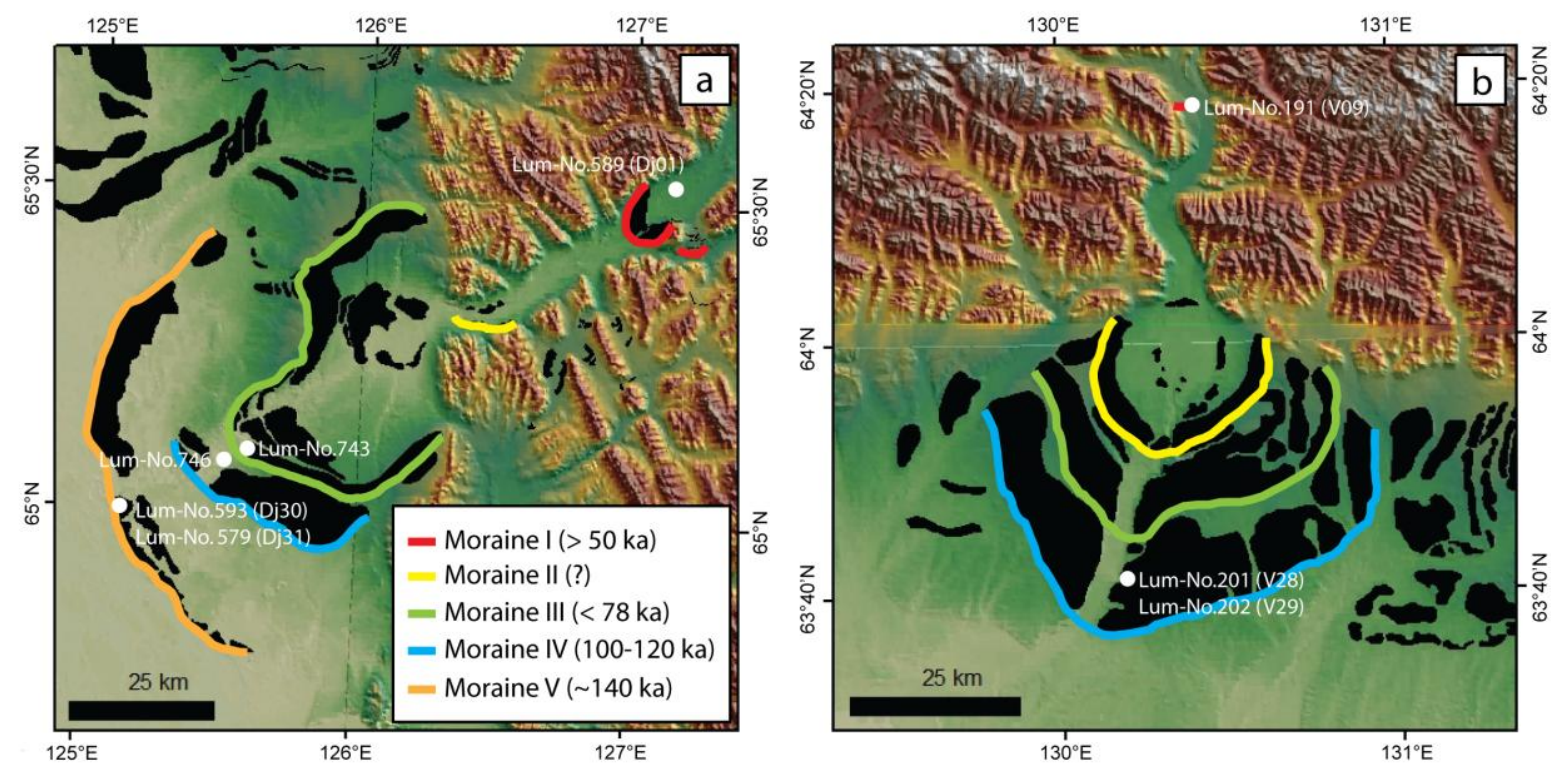

Figure 8. Moraines (black) mapped within (a) the Djanushka valley and (b) Tumara River valley, in the SW sector of the Verkhoyansk Mountains. Coloured lines reflect the extent of glaciation at various periods during the past $\sim 140 \mathrm{ka}$. Margins are constrained by published age-estimates (from Stauch et al., 2007; Zech et al., 2011). Dated sites are shown as white dots with associated sample labels (see table 2 for details). See figure 1 for site locations. 


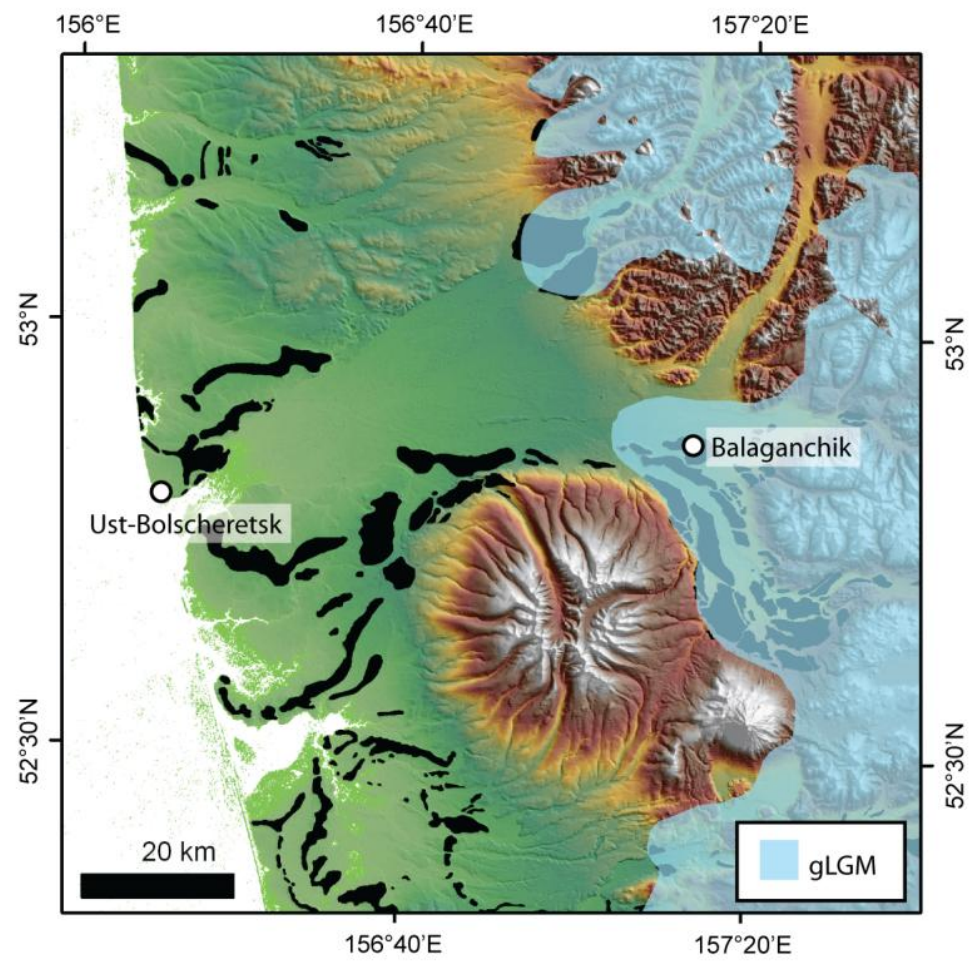

Figure 9. Moraines (black) upon the coastal lowlands of SW Kamchatka. The blue shaded region reflects the extent of ice during the global Last Glacial Maximum. Sites where tephra has been found overlying glacial deposits (see Bäumler and Zech, 2000) are shown as white dots with associated sample labels (details of which can be found in table 2). It is from this region that Nürnberg et al. (2011) suggest marine-terminating glaciers discharged ice-bergs into the Okhotsk Sea at various periods during the past $140 \mathrm{ka}$. See figure 1 for site location. 


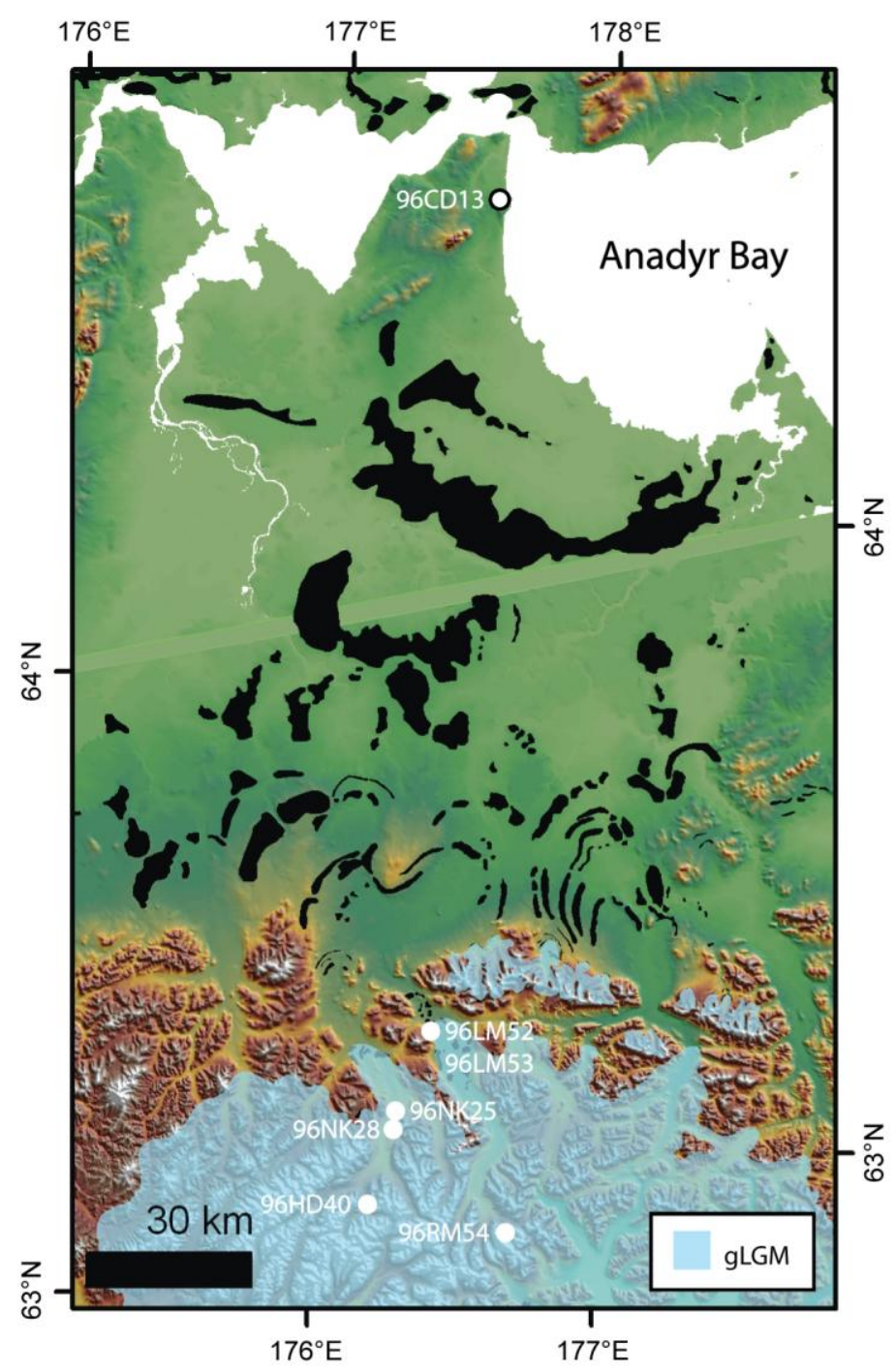

Figure 10. Moraines (black) within the northern sector of the Koryak Highlands. The blue shaded region reflects the extent of ice during the global Last Glacial Maximum. Margins are constrained by published age-estimates (from Gualtieri et al., 2000). Dated sites are shown as white dots with associated sample labels (see table 2 for details). See figure 1 for site location. 


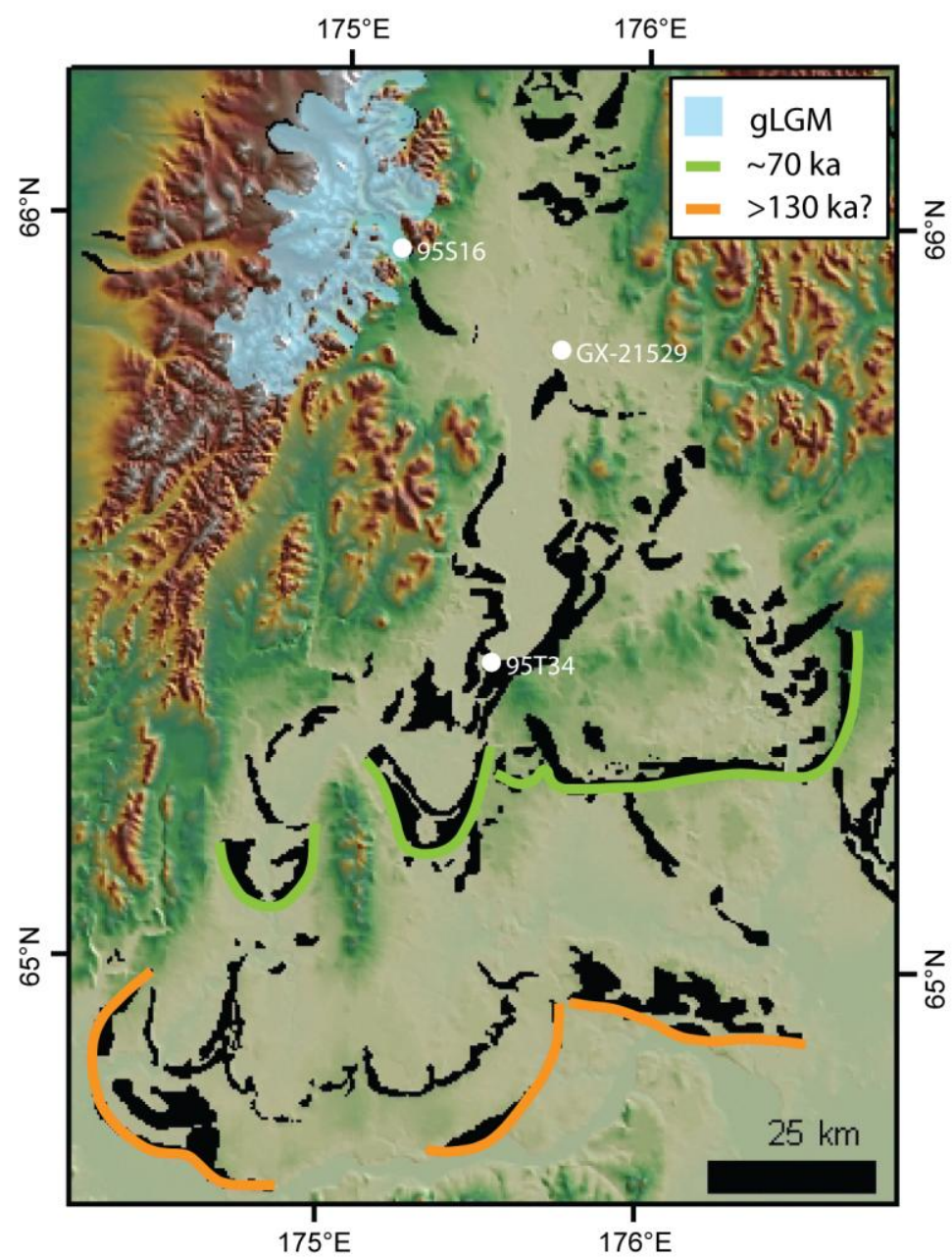

Figure 11. Moraines (black) upon the Anadyr Lowland region of the Chukchi Peninsula. Coloured lines reflect the possible extent of glaciation during the past $\sim 140 \mathrm{ka}$. The blue shaded region reflects ice extent during the global Last Glacial Maximum. Margins are constrained by published age-estimates (from Brigham-Grette et al., 2003). Dated sites are shown as white dots with associated sample labels (see table 2 for details). See figure 1 for site location. 


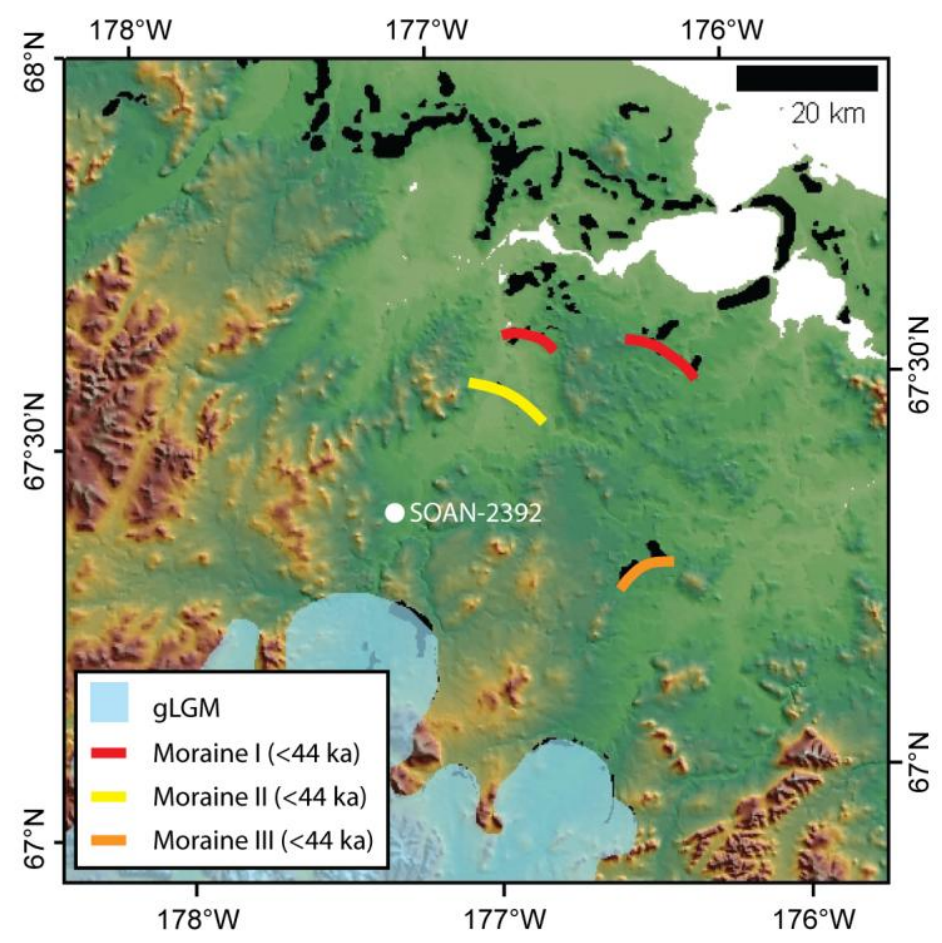

Figure 12. Moraines (black) upon the Vankarem Lowland region of the Chukchi Peninsula. Coloured lines reflect moraine sequences considered (by Laukhin, 1997; and Laukhin et al., 2006) to correlate with partially-dated till deposits studied in a series of mines. The blue shaded region reflects the extent of ice during the global Last Glacial Maximum. Margins are constrained by published age-estimates (from Laukhin et al., 1989). The Dated site is shown as a white dot with an associated sample label (see table 2 for details). See figure 1 for site location. 

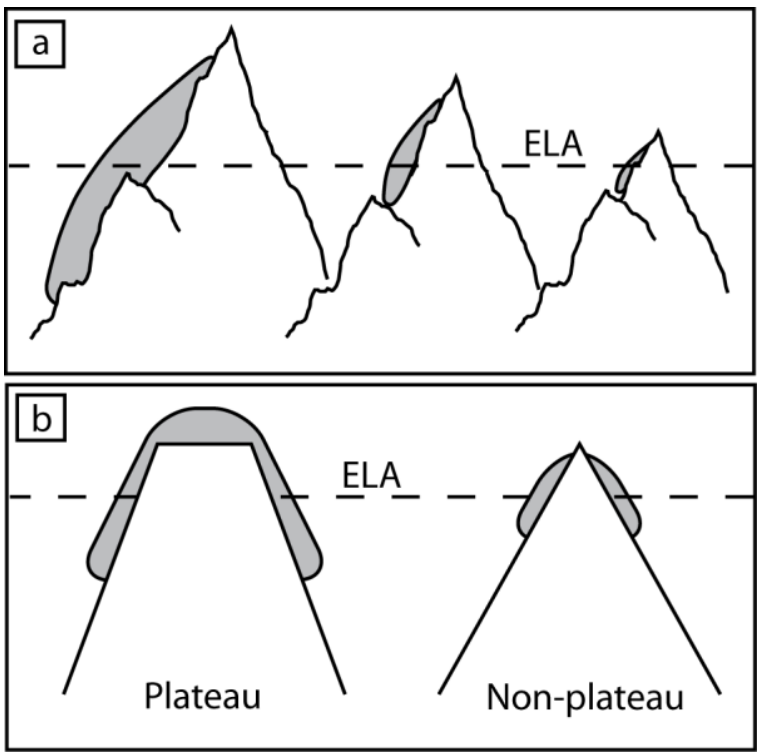

Figure 13. Illustration of potential topographic controls upon glacier dimensions. Under uniform climatic conditions (i.e. a uniform ELA), (a) mountain height, and (b) plateau and non-plateau topography, can lead to variations in glacier dimensions (figure based upon Barr, 2009). 

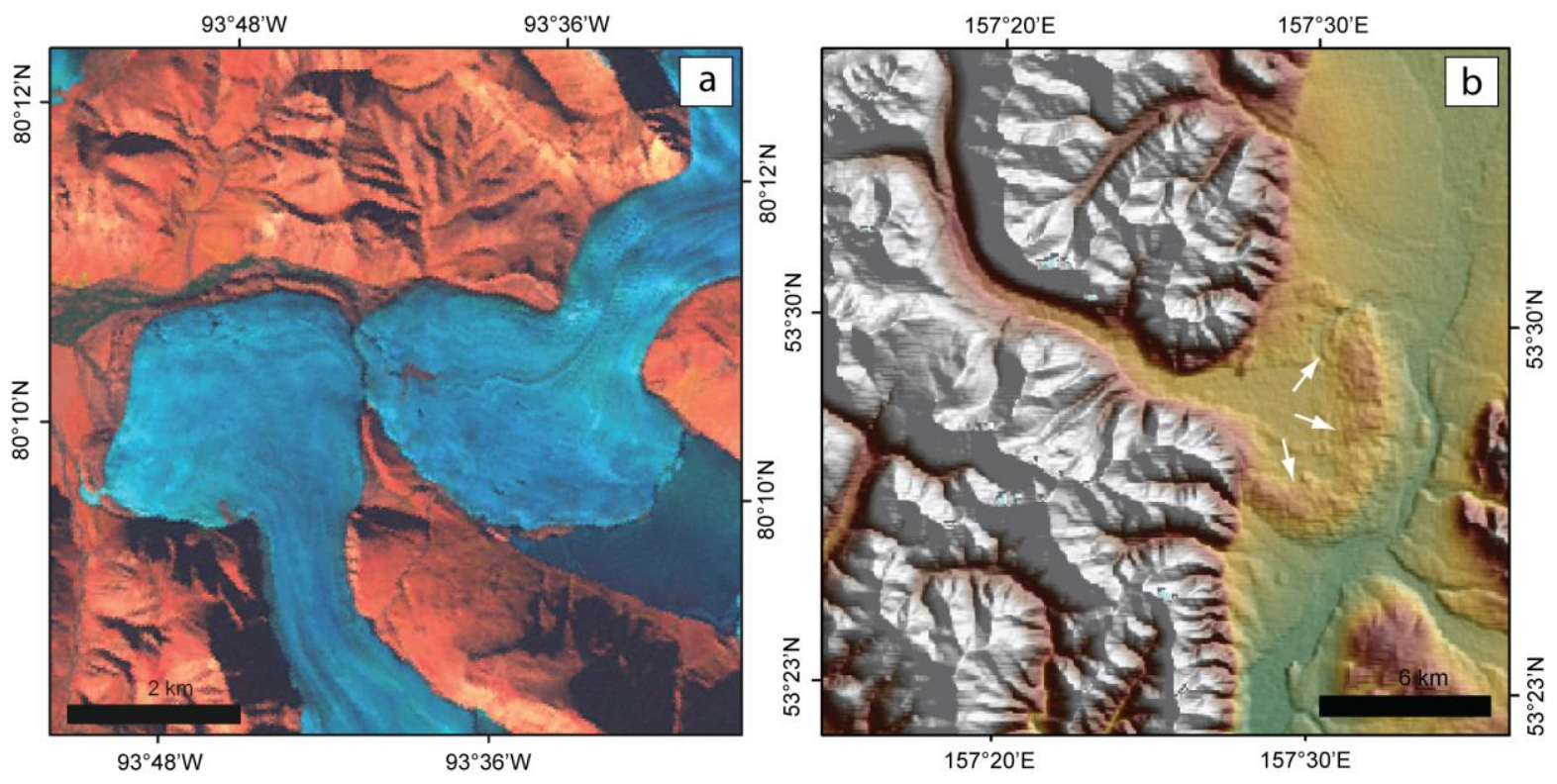

Figure 14. (a) Piedmont glaciers upon Axel Heiberg Island, Arctic Canada (b) Piedmont moraine (marked with arrows) in southern Kamchatka. See figure 1 for location of moraine site. 
Table 1. Details of the data sources used for moraine mapping

\begin{tabular}{|c|c|c|c|}
\hline Source & Technical properties & $\begin{array}{l}\text { Spatial } \\
\text { resolution }\end{array}$ & Acknowledgement/Source \\
\hline $\begin{array}{lr}\text { Landsat } & 7 \\
\text { ETM+ satellite } \\
\text { images }\end{array}$ & $\begin{array}{l}\text { - Bands } 5,4,2 \\
\text { - Panchromatic band } 8\end{array}$ & $\begin{array}{l}-30 \mathrm{~m} \\
-15 \mathrm{~m}\end{array}$ & $\begin{array}{l}\text { Global Land Cover Facility } \\
\text { (University of Maryland). } \\
\text { http://glcf.umiacs.umd.edu/ }\end{array}$ \\
\hline $\begin{array}{l}\text { ASTER } \\
\text { GDEM2 }\end{array}$ & $\begin{array}{l}\text { DEM built through photogrammetry from } \\
\text { ASTER satellite images }\end{array}$ & $\begin{array}{l}1 \quad \text { arc-second } \\
\text { (approx. } 30 \mathrm{~m} \text { ) }\end{array}$ & $\begin{array}{l}\text { NASA \& } \quad \text { \& } \\
\text { http://www.gdem.aster.ersdac.or.jp }\end{array}$ \\
\hline VFP DEM & $\begin{array}{l}\text { Created by digitising contours from a } \\
\text { 1:200,000 topographic map series }\end{array}$ & $90 \mathrm{~m}$ (approx.) & de Ferranti (2010) \\
\hline
\end{tabular}

Table 2. Database of published age-estimates, used to constrain former ice extent in Far NE Russia. All radiocarbon ages are calibrated using the IntCalo9 Curve (Reimer et al 2009).

\begin{tabular}{|c|c|c|c|c|c|c|c|c|c|c|c|}
\hline Sample & Site Name & Latitude $^{\circ} \mathrm{N}$ & Longitude $^{\circ} \mathrm{E}$ & Dated Material & Stratigraphic position & $\begin{array}{l}\text { Elevation } \\
\text { (m.asl) }\end{array}$ & $\begin{array}{l}\text { Dating } \\
\text { Technique }\end{array}$ & $\begin{array}{l}\text { Uncorrected } \\
\text { radiocarbon } \\
\text { age }\left({ }^{14} \mathrm{C} \text { yr BP }\right)\end{array}$ & $\begin{array}{l}\text { Calibrated } / \mathrm{c} \\
\text { alendar age } \\
\text { (kyr BP) }\end{array}$ & Comments & $\begin{array}{l}\text { Source } \\
\text { Reference }\end{array}$ \\
\hline $\begin{array}{ll}\text { Lum-No.191 (V09) } \\
\end{array}$ & Tumara River & 64.317 & 130.400 & Aeolian & $\begin{array}{l}\text { Surface aeolian deposit } \\
\text { covering sediments of } \\
\text { glaciofluvial outwash } \\
\text { plain }\end{array}$ & 350 & 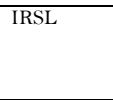 & & $\begin{array}{l}52,800 \\
4,100\end{array}$ & Minimum age for fluvioglacial materials beneath. & $\begin{array}{l}\text { Stauch } \\
(2007)\end{array}$ \\
\hline $\begin{array}{ll}\text { Lum-No.201 (V28) } \\
\end{array}$ & Tumara River & 63.700 & 130.170 & Sand & Fluvial sand above a till & 100 & IRSL & & $\begin{array}{l}123,000 \quad \pm \\
10,000\end{array}$ & Provides minimum age for till beneath & $\begin{array}{l}\text { Stauch } \\
(2007)\end{array}$ \\
\hline Lum-No.202 (V29) & Tumara River & 63.700 & 130.170 & Sand & Fluvial sand above a till & 100 & IRSL & & $\begin{array}{l}97,600 \quad \pm \\
6,800\end{array}$ & Provides minimum age for till beneath & $\begin{array}{l}\text { Stauch } \\
(2007)\end{array}$ \\
\hline Lum-No.589 (Djo1) & Dyanushka River & 65.517 & 127.100 & Aeolian & $\begin{array}{l}\text { Surface aeolian deposits } \\
\text { abover lacustrine } \\
\text { sediments, and and } \\
\text { upstream of moraine }\end{array}$ & 210 & IRSL & & $\begin{array}{l}39,700 \\
3,100\end{array}$ & Provides minimum age for downstream moraine & $\begin{array}{l}\text { Stauch } \\
(2007)\end{array}$ \\
\hline Lum-No.593 (Djs0) & $\begin{array}{l}\text { Dyanushka River } \\
\text {. }\end{array}$ & 65.017 & 125.100 & Sand & $\begin{array}{l}\text { Sand layer above small } \\
\text { band of till deposits }\end{array}$ & 95 & IRSL & & $\begin{array}{ll}135,000 & \pm \\
9,000 & \end{array}$ & Provides minimum age for till beneath & $\begin{array}{l}\text { Stauch } \\
(2007)\end{array}$ \\
\hline Lum-No.579(Djs1) & Dyanushka River & 65.017 & 125.100 & Sand & $\begin{array}{l}\text { Sand layer below small } \\
\text { band of till deposits }\end{array}$ & 95 & IRSL & & $\begin{array}{ll}1441,000 \\
10,000\end{array}$ & Provides maximum age for till above & $\begin{array}{l}\text { Stauch } \\
(2007)\end{array}$ \\
\hline Lum-No.743 & 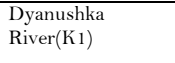 & 65.142 & 125.554 & Silty sand & $\begin{array}{l}\text { Sample from unit below } \\
\text { till }\end{array}$ & 152 & IRSL & & $\begin{array}{l}79,100 \quad \pm \\
5,500\end{array}$ & Provides maximum age for till above & 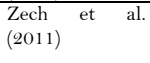 \\
\hline Lum-No.746 & $\begin{array}{l}\text { Dyanushka } \\
\text { River(K3) }\end{array}$ & 65.075 & 125.506 & Loamy silt & 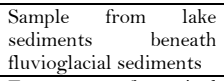 & 98 & IRSL & & $\begin{array}{l}119,000 \quad \pm \\
8,000\end{array}$ & Provides maximum age fluvioglacial materials above & $\begin{array}{l}\text { Zech et al. } \\
(2011)\end{array}$ \\
\hline $95 \mathrm{~S} 16$ & $\begin{array}{l}\text { Kuveveem } \\
\text { valley }\end{array}$ & 65.970 & 175.202 & Boulder & $\begin{array}{l}\text { From crest of terminal } \\
\text { moraine }\end{array}$ & 150 & $\mathrm{CN}^{36} \mathrm{Cl}$ & & $\begin{array}{l}23,600 \\
1,817\end{array}$ & $\begin{array}{l}\text { Provides a minimum age for moraine construction and } \\
\text { hence deglaciation }\end{array}$ & $\begin{array}{l}\text { Brigham-Grette } \\
\text { et al. (2003) }\end{array}$ \\
\hline
\end{tabular}




\begin{tabular}{|c|c|c|c|c|c|c|c|c|c|c|c|}
\hline $95 \mathrm{~T} 34$ & $\begin{array}{ll}\begin{array}{l}\text { Tanyurer } \\
\text { valley }\end{array} & \text { River } \\
\end{array}$ & 65.417 & 175.500 & Bedrock & $\begin{array}{l}\begin{array}{l}\text { Glacially } \\
\text { bedrock }\end{array} \\
\text { moulded }\end{array}$ & 130 & $\mathrm{CN}^{{ }^{36} \mathrm{Cl}}$ & & $\begin{array}{l}69,600 \quad \pm \\
4,733\end{array}$ & Provides minimum ages since deglaciation & $\begin{array}{l}\text { Brigham-Grette } \\
\text { et al. (2003) }\end{array}$ \\
\hline GX-21529 & $\begin{array}{l}\text { Chumyveem River } \\
\text { valley }\end{array}$ & 65.825 & 175.714 & Wood & $\begin{array}{l}\text { At base of undisturbed } \\
\text { terrace }\end{array}$ & & ${ }^{{ }^{14} \mathrm{C}}$ & $>42,980$ & $>45,984$ & $\begin{array}{l}\text { Provides minimum ages since deglaciation } \\
\end{array}$ & $\begin{array}{l}\text { Brigham-Grette } \\
\text { et al. (2003) }\end{array}$ \\
\hline SOAN-2392 & $\begin{array}{l}\text { Vankarem } \\
\text { Lowland }\end{array}$ & 67.394 & -177.459 & Peat and Wood & $\begin{array}{lc}\text { Alluvial } & \text { sediments } \\
\text { underlying } & \text { three till } \\
\text { layers } & \text { and } \\
\text { one } & \text { overlying }\end{array}$ & & ${ }^{14} \mathrm{C}$ & $39,300 \pm 1,130$ & $\begin{array}{l}4,487 \\
814\end{array}$ & Provides a maximum age for three overlying layers of till & $\begin{array}{l}\text { Laukhin et al } \\
(1989)\end{array}$ \\
\hline 96LM52 & Lake Mainitz & 63.322 & 176.618 & $\begin{array}{l}\text { Rounded } \\
\text { Cobbles }\end{array}$ & $\begin{array}{l}\text { Upon a terrace } 13.8 \mathrm{~m} \\
\text { above Lake Mainitz }\end{array}$ & 140 & $\mathrm{CN}^{36} \mathrm{Cl}$ & & $\begin{array}{ll}10,080 & \pm \\
846\end{array}$ & $\begin{array}{l}\text { Provides minimum age since deglaciation. Gualtieri et al. } \\
\text { (2000) consider the possibility that the age may be } \\
\text { anomalously young }\end{array}$ & $\begin{array}{l}\text { Gualtieri et al. } \\
(2000)\end{array}$ \\
\hline $96 \mathrm{LM} 53$ & Lake Mainitz & 63.322 & 176.618 & $\begin{array}{l}\text { Rounded } \\
\text { Cobbles }\end{array}$ & $\begin{array}{l}\text { Upon a terrace } 13.8 \mathrm{~m} \\
\text { above Lake Mainitz }\end{array}$ & 140 & $\mathrm{CN}^{{ }^{36} \mathrm{Cl}}$ & & $\begin{array}{ll}19,510 & \pm \\
2,265\end{array}$ & $\begin{array}{l}\text { Provides minimum age since deglaciation. Gualtieri et al. } \\
\text { (20oo) suggest this age may be anomalously old, and } \\
\text { probably represents inherited }{ }^{3} \mathrm{Cl}\end{array}$ & $\begin{array}{l}\begin{array}{l}\text { Gualtieri et al. } \\
(2000)\end{array}\end{array}$ \\
\hline 96RM54 & Rocamaha Lake & 62.975 & 176.768 & Boulder & $\begin{array}{l}\text { From surface of cirque } \\
\text { terminal moraine }\end{array}$ & 350 & $\mathrm{CN}^{\mathrm{SB} \mathrm{Cl}}$ & & $\begin{array}{l}10,850 \\
1,011\end{array}$ & $\begin{array}{l}\text { Provides as a minimum age since deglaciation and moraine } \\
\text { stabilisation }\end{array}$ & $\begin{array}{l}\text { Gualtieri et al. } \\
(2000)\end{array}$ \\
\hline $96 \mathrm{HD} 40$ & Nahodka Valley & 63.063 & 176.271 & Boulder & $\begin{array}{l}\text { Upon a terrace } 14.3 \mathrm{~m} \\
\text { above river level }\end{array}$ & 350 & $\mathrm{CN}^{{ }^{36} \mathrm{Cl}}$ & & $\begin{array}{ll}16,650 \\
1,163\end{array}$ & $\begin{array}{l}\text { Provides a minimum age for deglaciation (oldest of four } \\
\text { CN dated samples from this site) }\end{array}$ & $\begin{array}{l}\text { Gualtieri et al. } \\
(2000)\end{array}$ \\
\hline $96 \mathrm{NK} 28$ & $\begin{array}{l}\text { Nygchekveem } \\
\text { Valley }\end{array}$ & 63.180 & 176.418 & Boulder & $\begin{array}{l}\text { From surface of moraine } \\
\text { bounding } \\
\text { Lake }\end{array}$ & 260 & $\mathrm{CN}^{36} \mathrm{Cl}$ & & $\begin{array}{l}19,760 \quad \pm \\
2,843\end{array}$ & $\begin{array}{l}\text { Provides a minimum age for moraine construction and } \\
\text { hence deglaciation (oldest of four samples from the two } \\
\text { moraines which bound the lake) }\end{array}$ & $\begin{array}{l}\text { Gualtieri et al. } \\
(2000)\end{array}$ \\
\hline $96 \mathrm{NK} 25$ & $\begin{array}{l}\text { Nygchekveem } \\
\text { Valley }\end{array}$ & 63.213 & 176.440 & Boulder & From lateral moraine & 240 & $\mathrm{CN}^{36} \mathrm{Cl}$ & & $\begin{array}{ll}21,650 \\
3,364\end{array}$ & Minimum age since deglaciation & $\begin{array}{l}\text { Gualtieri et al. } \\
(2000)\end{array}$ \\
\hline $96 \mathrm{CD} 13$ & Cape Dionysia & 64.596 & 177.377 & Bedrock & $\begin{array}{ll}\begin{array}{l}\text { Exposed } \\
\text { surface }\end{array} & \text { bedrock } \\
\end{array}$ & 160 & $\mathrm{CN}^{36} \mathrm{Cl}$ & & $\begin{array}{ll}52,990 & \pm \\
4,109\end{array}$ & $\begin{array}{l}\text { Provides minimum age since deglaciation } \\
\end{array}$ & $\begin{array}{l}\begin{array}{l}\text { Gualtieri et al. } \\
(2000)\end{array} \\
\text { (2) }\end{array}$ \\
\hline MAG-1390 & $\begin{array}{l}\text { Ulachan-Chistai } \\
\text { Range }\end{array}$ & 64.973 & 146.592 & Peat & $\begin{array}{l}\text { Section within terrace } \\
7-10 \mathrm{~m} \text { above river level }\end{array}$ & & ${ }^{{ }^{14} \mathrm{C}}$ & $6,135 \pm 60$ & $6,989 \pm 40$ & $\begin{array}{l}\text { Provides a minimum age since deglaciation (oldest of five } \\
\text { radiocarbon dates derived from this site) }\end{array}$ & $\begin{array}{l}\begin{array}{l}\text { Glushkova } \\
(2001)\end{array} \\
\text { (20) }\end{array}$ \\
\hline WHG-819/AA6884 & $\begin{array}{l}\text { Bolshoi } \text { Anachag } \\
\text { Range (Sosednee } \\
\text { Lake) }\end{array}$ & 62.059 & 149.523 & $\begin{array}{l}\text { Aleurite with } \\
\text { organics }\end{array}$ & $\begin{array}{l}\text { Sediment } \\
\text { from lake bed }\end{array}$ & & ${ }^{{ }^{14} \mathrm{C}}$ & $21,860 \pm 235$ & $\begin{array}{ll}26,289 \\
366\end{array}$ & Provides a minimum age since deglaciation & $\begin{array}{l}\text { Glushkova } \\
(2001)\end{array}$ \\
\hline CAMS-14589 & $\begin{array}{l}\text { Bolshoi Anachag } \\
\text { Range (Elgennya } \\
\text { Lake) }\end{array}$ & 62.099 & 149.002 & $\begin{array}{l}\text { Aleurite with } \\
\text { organics }\end{array}$ & $\begin{array}{l}\text { Sediment } \text { recovered } \\
\text { from lake bed }\end{array}$ & & ${ }^{144} \mathrm{C}$ & $15,290 \pm 80$ & $18,589 \pm 78$ & Provides a minimum age since deglaciation & $\begin{array}{l}\text { Glushkova } \\
(2001)\end{array}$ \\
\hline $\mathrm{n} / \mathrm{a}$ & Ust-Bolscheretsk & 52.785 & 156.183 & Tephra & 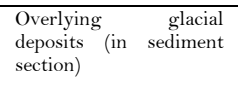 & & ${ }^{14} \mathrm{C}$ & $\sim 40,000$ & 44,062 & $\begin{array}{l}\text { Tephra (Opala Volcano) provides a minimum age for } \\
\text { deposition of underlying glacial deposits. Also provides } \\
\text { minimum age since deglaciation }\end{array}$ & $\begin{array}{l}\text { Reported in } \\
\text { Bäumler and } \\
\text { Zech (2000) }\end{array}$ \\
\hline $\mathrm{n} / \mathrm{a}$ & $\begin{array}{ll}\text { West } \\
\text { Balaganchik }\end{array}$ & 52.867 & 157.209 & Tephra & $\begin{array}{lr}\begin{array}{l}\text { Overlying } \\
\text { deposits }\end{array} \text { (in } & \text { glacial } \\
\text { section) } & \text { sediment }\end{array}$ & & ${ }^{144} \mathrm{C}$ & $\sim 7,800$ & 8,564 & $\begin{array}{l}\text { Tephra (Lake Il'inskaya eruption) provides a minimum age } \\
\text { for deposition of underlying glacial deposits (M1 and M2 } \\
\text { glacial deposits). Also provides minimum age since } \\
\text { deglaciation }\end{array}$ & $\begin{array}{l}\text { Reported in } \\
\text { Bäumler and } \\
\text { Zech (2000) }\end{array}$ \\
\hline $\mathrm{n} / \mathrm{a}$ & $\begin{array}{l}\text { Plotnikova Valley } \\
\end{array}$ & 52.867 & 157.209 & Tephra & $\begin{array}{lr}\begin{array}{l}\text { Overlying } \\
\text { deposits }\end{array} \text { (in } & \text { glacial } \\
\text { section) } & \text { sediment }\end{array}$ & & ${ }^{144} \mathrm{C}$ & $\sim 7,800$ & 8,564 & $\begin{array}{l}\text { Tephra (Lake Il'inskaya eruption) provides a minimum age } \\
\text { for deposition of underlying glacial deposits (M1 and M2 } \\
\text { glacial deposits). Also provides minimum age since } \\
\text { deglaciation }\end{array}$ & $\begin{array}{l}\text { Reported in } \\
\text { Bäumler and } \\
\text { Zech (2000) }\end{array}$ \\
\hline
\end{tabular}


